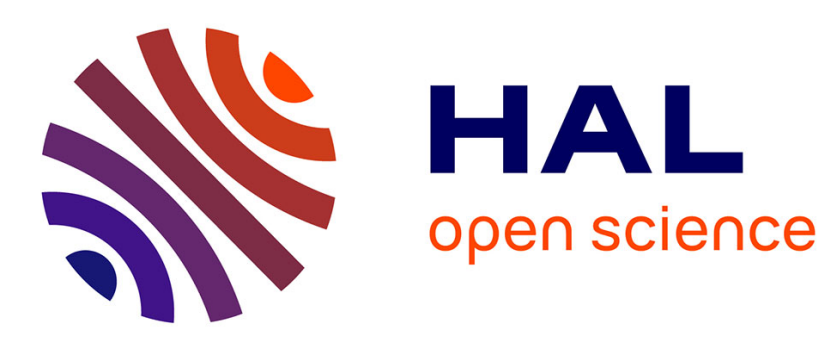

\title{
The repertoire of family A-peptide GPCRs in archaic hominins
}

\author{
Xavier Mata, Gabriel Renaud, Catherine Mollereau
}

\section{To cite this version:}

Xavier Mata, Gabriel Renaud, Catherine Mollereau. The repertoire of family A-peptide GPCRs in archaic hominins. Peptides, 2019, 122, pp.170154. 10.1016/j.peptides.2019.170154 . hal-02322476

\section{HAL Id: hal-02322476 https://hal.science/hal-02322476}

Submitted on 18 Nov 2020

HAL is a multi-disciplinary open access archive for the deposit and dissemination of scientific research documents, whether they are published or not. The documents may come from teaching and research institutions in France or abroad, or from public or private research centers.
L'archive ouverte pluridisciplinaire HAL, est destinée au dépôt et à la diffusion de documents scientifiques de niveau recherche, publiés ou non, émanant des établissements d'enseignement et de recherche français ou étrangers, des laboratoires publics ou privés. 


\title{
The repertoire of family A-peptide GPCRs in archaic hominins
}

\author{
Xavier Mata ${ }^{1}$, Gabriel Renaud $^{2}$ and Catherine Mollereau ${ }^{1 *}$ \\ ${ }^{1}$ Laboratoire Anthropobiologie Moléculaire et Imagerie de Synthèse (AMIS), Université de \\ Toulouse, CNRS, UPS, Toulouse, France. \\ ${ }^{2}$ Centre for GeoGenetics, Natural History Museum of Denmark, University of Copenhagen, \\ Copenhagen K, Denmark.
}

*Correspondence:

Corresponding Author

Catherine.mollereau-manaute@ipbs.fr

\begin{abstract}
Given the importance of G-protein coupled receptors in the regulation of many physiological functions, deciphering the relationships between genotype and phenotype in past and present hominin GPCRs is of main interest to understand the evolutionary process that contributed to the present-day variability in human traits and health. Here, we carefully examined the publicly available genomic and protein sequence databases of the archaic hominins (Neanderthal and Denisova) to draw up the catalog of coding variations in GPCRs for peptide ligands, in comparison with living humans. We then searched in the literature the functional changes, phenotypes and risk of disease possibly associated with the detected variants. Our survey suggests that Neanderthal and Denisovan hominins were likely prone to lower risk of obesity, to enhanced platelet aggregation in response to thrombin, to better response to infection, to less anxiety and aggressiveness and to favorable sociability. While some archaic variants were likely advantageous in the past, they might be responsible for maladaptive disorders today in the context of modern life and/or specific regional distribution. For example, an archaic haplotype in the neuromedin receptor 2 is susceptible to confer risk of diabetic nephropathy in type 1 diabetes in present-day Europeans. Paying attention to the pharmacological properties of some of the archaic variants described in this study may be helpful to understand the variability of therapeutic efficacy between individuals or ethnic groups.
\end{abstract}

Keywords: GPCR, peptides, missense variants, Neanderthal, Denisova 


\section{Introduction}

The phenotypic diversity of living people has been spatio-temporally shaped in most part, by selective adaptation to environmental and climate changes, nutritional resources, epidemics and socio-cultural influences (1-3). Nevertheless, ancient DNA sequencing has recently revealed that adaptive selection could also result from introgression of genes from extinct human species into the genome of anatomically modern humans (AMH) by admixture $(4,5)$. The archaic hominins Neanderthals (6-8) and the recently identified Denisovan group (9-12) have occupied Europe and central Asia from 600 thousand years ago (kya) and their decline between 40 and 30 kya coincides with the dispersal of AMH throughout Eurasia after they left Africa 60-80 kya (13-15). The release of their genomes has evidenced recurrent interbreeding events with AMH $(16,17)$, which contributed to deeply change our vision of the human evolutionary tree (18). It is estimated that $2-3 \%$ of the genome of present-day non-African people originates from Neanderthal and that $5 \%$ of the genome of living Oceanians and Melanesians is from Denisova. A part of these archaic traces contributes to an archaic phenotypic legacy in present-day genomes $(19,20)$ that shapes some human physical traits, behavior and physiological functions, and influences health and disease related to metabolism, immune system or brain functions $(4,21,22)$. Since adaptive introgression are specific to particular local conditions, some ancient traits may become maladaptive in another context leading to disease or, vice versa, could become protective $(1,5,19,20)$.

Access to ancient genomes provides now the opportunity to analyze the polymorphisms present in archaic hominin protein sequences (23). By comparing with modern humans, it allows to get insights into the phenotypic variability among present and past hominins at different levels (molecular, cellular, biological, physiological and pathophysiological). A number of coding variations have been described in proteins involved in skin and hair pigmentation, skeletal morphology, behavior (23), immunity (24) and olfaction (25). But to date, only a few examples have been functionally characterized in comparison to modern humans.

G-protein coupled receptors (GPCRs) play an essential role in regulating the main biological and physiological functions of the organism. Interestingly, GPCRs are highly polymorphic (2628), so that deciphering the relationships between genotype and phenotype in past and present hominin GPCRs is therefore important to understand the evolutionary process that contributed to the present-day variability in human traits and health (29).

In this study, we have thus drawn up the catalog of the archaic coding variations in GPCRs, specifically GPCRs for peptides, in comparison with living humans, and searched in the literature the possible functional changes, phenotypes and risk of disease associated with these variations. Tracking such non-synonymous polymorphisms is not only able to reveal ancient phenotypes, physical traits and physiology related to GPCRs, but can also be relevant to understand some pathologies or maladaptive disease inherited from the past and potentially nowadays restricted to particular ethnic populations (evolutionary medicine).

GPCRs, also called seven-transmembrane domain (7TM) receptors (fig.1), compose the largest family of proteins in a lot of diverse organisms. In humans, it represents $\geq 800$ genes 
(including about 450 olfactory receptors) that account for 1-3\% of the genome (30). Although variable in sequences, GPCRs share a highly conserved protein structure with specific motif signatures, suggesting high evolutionary constraints $(28,31,32)$. Based on sequence homology, the N-terminus length and specific conserved motifs along the TMs (fig.1), the human nonolfactory GPCRs (about 350 proteins) have been subdivided into five families: Rhodopsinlike/Family A, Secretin-like/Family B, Family C including the metabotropic glutamate and $\mathrm{GABA}_{\mathrm{B}}$ receptors, Adhesion receptors and Frizzled/Taste (TAS2) receptors (30). The Rhodopsin-like/Family A is the largest family, regrouping $90 \%$ of the receptors, that includes receptors for neurotransmitters, peptides, lipids, hormones, opsins and odors.

GPCRs are expressed at the surface of many cell types where they transduce the signal of a large variety of extracellular stimuli (light, ions, lipids, nucleotides, odorant molecules, neurotransmitters, neuropeptides and hormones), mainly through the activation of G-proteins (fig.1). In consequence, GPCRs are involved in a large panel of functions such as vision, olfaction, metabolism, reproduction, neurotransmission, cardiovascular and immunity $(26,31)$, but also play part in metabolic, hormonal and neurological disorders (26, 33-35). GPCRs constitute therefore one of the main target of current therapeutic drugs (30-40\% of marketed medicines).

Owing to their crucial role in the organism, it is not surprising to find GPCR genes located in genomic regions showing strong signature of positive selection (32), with the exception of the olfactory receptors that accumulate deleterious non-synonymous polymorphisms (nsSNP) and show relaxed negative selection $(25,36)$. As a correlate, mutations or deletions in the coding sequence of GPCRs are responsible for human pathologies (26, 33-35). Depending on the location (extra- or intra- cellular domains, transmembrane segments) and the type of amino acid substitutions, mutations may influence agonist binding, receptor activation, posttranslational regulation, partner interaction, maturation or cell surface expression. Loss-offunction mutations give poorly- or non-functional receptors exhibiting either a low affinity for endogenous agonist, or a defect in signal transduction, or an increased desensitization or a misfolded protein that prevents proper localization to the plasma membrane. Examples of diseases caused by such mutations are nephrogenic diabetes insipidus (AVPR2 vasopressin receptor), retinis pigmentosa (Rhodopsin), obesity (MC4 melanocortin receptor), hypogonadism (Gonadotropin-releasing hormone and Luteinizing hormone receptors, kisspeptin receptor) and hypothyroidism (Thyroid stimulating hormone receptor). In some cases however, such as the chemokine receptors CCR5 or DUFFY, inactivation of the receptor may instead confer protection against pathogen entry (34). Gain-of-function mutations result in more active receptors due to improved agonist binding or receptor signaling, or decreased desensitization. These gain-of-function mutations contribute for instance to WHIM syndrome (CXCR4 chemokine receptor), nephrogenic syndrome of inappropriate antidiuresis (AVPR2), non-autoimmune hyperthyroidism (TSH receptor), early puberty (Kiss1, LH, FSH receptors).

Compared to other human genes, GPCRs exhibit a high frequency of non-synonymous polymorphisms (26-28). A number of 14192 nsSNP have been identified in 108 GPCRs targeted by drugs, with about 128 rare and 3.7 common variants per receptor (26). On average, each individual harbors 68 GPCR missense variants, including one loss-of-function mutation in $0.2 \%$ of the individuals. They are preferentially located in the $\mathrm{N}$ and $\mathrm{C}$-terminal ends, and 
in the TM domains of the receptors where they are susceptible to disrupt receptor function (26, 27). The high degree of polymorphism in GPCRs probably takes part in the inter-individual variability of some human phenotypes and biological responses (26-28). As examples, variants in the MC1 melanocortin receptor, or in the olfactory receptor for androstenone (OR7D4), contribute to skin and hair pigmentation diversity (37-39) and to olfactive preference (40), respectively. Among the Rhodopsin-like/Family A, the receptors for peptides are highly polymorphic and are part of the receptors causing mutation-induced diseases $(26,34)$. They also contribute to phenotypic variability.

Given their major role in the regulation of metabolic and psychological functions, studying the polymorphic variability of the Rhodopsin-like/Family A peptide GPCRs in the context of human evolution can provide clues not only to help deciphering some aspect of human past phenotype and physiology, but also to better understand the origin of present-day human diseases. In this study, we have therefore analyzed the repertoire of peptide GPCRs in the genome of the extinct hominins, Neanderthals and Denisovans, in order to reveal ancient phenotypes related to physical traits and physiology, which could be also indicative of maladaptation to present-day lifestyle.

\section{Methods}

The Protein or DNA sequences from Neanderthal and Denisova hominins were collected from publicly available databases and analyzed using open source software as described below.

A total of 42395 transcript ID and associated protein sequences were retrieved from the Neanderthal exome database (http://cdna.eva.mpg.de/neandertal/exomes/proteins) which includes data from three bone specimens, Altaï (Altaï mountain cave, Siberia), Vi33.15 (Vindija cave, Croatia) and SD1253 (El Sidron cave, Spain), that were sequenced with $12.5 \mathrm{x}$ to $42 \mathrm{x}$ coverage (23). Among the 753 genes manually identified as GPCRs, 79 receptors corresponding to peptide receptors of the Rhodopsin-like/Family A (list in Table S1) were sorted according to the classification of the GPCR database (http://gpcrdb.org/). The 79 protein sequences from the Neanderthal exome catalog were then aligned to the corresponding Homo sapiens protein references and compared with the Pan troglodytes and Gorilla gorilla sequences by using Uniprot (http://www.uniprot.org/).

For the high-coverage (30x) Denisova (specimen 3) genome (9) and the other less-well covered (1.3x) Neanderthal sequences (Vi33.16, Vi33.25, Vi33.26 from the Vindija Cave, and Mez 1 from the Mezmaiskaya cave in the Caucasus) (6), the coding variations in the 79 receptor sequences were manually visualized on the Neanderthal Genome Analysis Consortium Tracks on the UCSC Genome Browser website (https://genome-euro.ucsc.edu/) aligned to the modern human GRCh37/hg19 Assembly (41).

In both cases (Neanderthal exome and Denisova 3 genome), ancient DNA had been treated by the USER mix (Uracil DNA glycosylase and DNA glycosylase-lyase endonuclease VIII) to remove uracils resulting from cytosine deamination $(9,23)$, the main damage on ancient DNA (42). Moreover, Neanderthal exome sequences were corrected for cytosine deamination (23). While limiting, but not totally excluding, possible misinterpretation due to residual damageinduced $\mathrm{C}>\mathrm{T}$ or $\mathrm{G}>\mathrm{A}$ changes, the detection of variants is however supported by the high coverage of these samples. The survey of the 79 GPCRS finally resulted in only 35 of them 
showing 55 amino acid variations with the human reference genome. For these variants, it is unlikely that every cytosine would have undergone deamination for every single fragment overlapping our sites of interest in high-coverage samples.

In the course of the study, the release of other archaic sequences offered the opportunity to get supplementary information on the 55 variants identified in the previous bioinformatics analyses. The new specimens include the high coverage (30x) genome of Vi33.19 (8) and of Vi87 (43) from the Vindija cave in Croatia and corresponding in fact to the same individual as Vi33.15, the four late Neanderthal samples (43) Goyet Q56-1 (Belgium), Spy 94a (Belgium), Les Cottés Z4-1514 (France) and Mezmaiskaya 2 (Caucasus) sequenced at a 1-2.7x coverage, and the low coverage sequence from the tooth of a new (specimen 2) Denisovan individual (11). The variant Call Format (VCF) files from Vi33.19 were downloaded from http://cdna.eva.mpg.de/neandertal/Vindija/VCF/Vindija33.19/ and analyzed by using the open source, web-based platform, Galaxy (https://usegalaxy.org/). The data were merged with those of Vi33.15 and Vi87 in the Tables. The bam files of Denisova 2 from the bioproject PRJEB20653 available at https://www.ebi.ac.uk/ena and those of the late Neanderthal genomes available at http://cdna.eva.mpg.de/neandertal/ were downloaded and analyzed by using SAMtools utilities (44) with the following constraints: mapping quality fixed to 25 , minimum fragment size of $35 \mathrm{bp}$, and use of duplicate removal for clonal PCR fragments. The lowcoverage nuclear DNA sequences from the Denisovan specimens 4 and 8 (12) were also investigated, but none of the position of interest were covered.

Single nucleotide variant information (frequency, phenotype, clinical significance) on the nsSNP found in archaic hominins were retrieved from the public genomic datasets such as the 1000 genome project and Exome Aggregation consortium available on the websites http://www.ensembl.org/ and http://exac.broadinstitute.org/ $(45,46)$. The impact of missense variations on receptor function was searched in the GPCR database (http://gpcrdb.org/) (47) and PubMed literature records (http://www.ncbi.nlm.nih.gov/pubmed).

Throughout the study, "archaic hominins" refers to the extinct hominins Neanderthals and Denisovans, "ancestral" variant (or allele) indicates that the variant is shared with chimpanzee and gorilla. Conversely, "derived" variant (or allele) indicates that the variant is not ancestral and differs from apes.

\section{Analysis of coding variants in archaic peptide GPCRs}

The alignment of the 79 archaic peptide GPCRs to the modern human protein reference database Uniprot or to the GRCh37/hg19 genome assembly yielded a total of 55 coding variations in 35 receptors (Tables 1 and 2). The missense variants are essentially located in the extra- or intra- cellular domains of the receptors (Table 2). 14 substitutions are located in the transmembrane domains whereas 29 are found in the $\mathrm{N}$ and $\mathrm{C}$ terminal ends and 13 in the extraor intra- cellular loops. They are therefore expected to alter receptor binding affinity and/or selectivity, and to regulate signaling response and desensitization (26).

Interestingly, the nsSNP found in Neanderthals and Denisovans are mainly derived (yellow color in Table 1), while modern humans mostly carry at the same position the ancestral allele 
in common with chimpanzee and gorilla (blue color in Table 1). A part of these archaic derived variants has not been described in present-day people (uncharacterized SNP in Table 1). This is in agreement with the previous observation that the high-coverage Denisova genome contains a high number of exclusive alleles (9). These uncharacterized archaic-specific variants can be however considered as reliable polymorphisms since they are shared among several individuals. It is the case for example of the substitutions in receptors Bombesin 3 (C390G), Neuromedin U1 (V72M), Neuropeptide FF2 (G28E and T375I), Neuropeptide S (I102V) and PAR2 (V125I) (Table 1). Most of the other missense variants identified in Neanderthal and Denisovan hominins correspond to present-day minor alleles, or are present at low $(0.1 \%-1 \%)$ to very low $(<0.1 \%)$ frequency, and are sometimes geographically restricted (Table 1), suggesting that GPCR archaic polymorphisms may persist today, at least in specific populations. These variants could trace back an ancient reminiscence of a common homo ancestor, or a signature of introgression (or conversely, incomplete suppression) of archaic polymorphisms in certain modern human populations.

The list of coding variations in archaic hominins compared to great apes (Gorilla gorilla and Pan troglodytes) and present-day human frequency is given in Table 1. The coverage of the mutations in DNA sequences is given in Table S2. The physiological role of receptors is described in Table S3. The functional consequences of receptor variants and their association to putative phenotypes and risk of disease in living humans are presented in Table 2 and discussed below.

\subsection{Derived variants common to Neanderthal and Denisovan hominins}

Denisovans and Neanderthals share a number of derived variants of interest at positions where the present-day worldwide major allele is ancestral (Table 1 and Figure 2).

\subsubsection{Melanocortin receptors}

The melanocortin receptors (MC1R to MC5R) respond to MSH (melanocyte-stimulating hormone) and ACTH (adrenocorticotropic hormone), two peptides derived from the proopiomelanocortin (POMC) precursor and playing important roles in human physiology (48).

MC4R controls feeding behavior and energy expenditure, and is one of the main genes involved in the dominant inherited forms of obesity (49-52). Agonist stimulation of MC4R by the satiating peptide $\alpha-\mathrm{MSH}$ decreases food intake, whereas stimulation by the endogenous antagonist AGRP stimulates appetite. Dysfunction of MC4R produces hyperphagia and fat mass increase, and is responsible for the most common forms of monogenic obesity (6\% of patients). Over $100 \mathrm{nsSNP}$ within the MC4R coding sequence have been identified in worldwide population, however with an unusual very low frequency, suggesting that the gene was under constraint purifying selection during human evolution $(49,51)$. Most of the nsSNP lead to loss-of-function mutations and are associated with severe and early-onset obesity (50, 52). Interestingly, all the covered archaic hominin MC4R sequences show a derived variant, V103I (rs2229616), that has been associated with a reduced risk of obesity $(50,52)$ and that is nowadays found at low (2-4\%) frequency in worldwide population (Table 1). Compared to carriers of the major ancestral allele V103, the individuals with the minor allele I103 have reduced waist circumference and metabolic parameters (triglyceride and high-density 
lipoprotein cholesterol levels) conferring $20 \%$ to $30 \%$ lower risk of obesity in the Caucasian and the East Asian populations, respectively $(50,52)$. Although this variant displays normal receptor function in terms of surface expression and agonist binding, some degree of constitutive activity and less sensitivity to the endogenous appetite stimulant peptide AGRP may explain its protective effect. Obesity constitutes a major health concern in the contemporary world. It is one example of diseases resulting from a maladaptive response to the recent changes in environment (more energy abundance) and way of life (less energy expenditure) (53). The fact that the V103I variant is found in Neanderthal and Denisovan individuals of different places and time suggests that the polymorphism was present at high frequency in archaic hominins and was probably specifically well-adapted to their environment. Since ancient hominins were probably exposed to frequent periods of starvation, the feeling of being less hungry was perhaps an advantage. Today, in a world of free access to a high-calorie diet, this archaic variant of MC4R expected to produce less appetite stimulation, may be healthier for the carriers.

In the course of human evolution and migrations, skin pigmentation is one of the traits having undergone selection during adaptation to climate changes and novel less sunny environments $(15,54,55) . \mathrm{MC} 1 \mathrm{R}$ is one of the major determinant of skin and hair pigmentation and of ultraviolet (UV) sensitivity in humans. A high number of SNPs (over 100) generating nonsynonymous mutations in MC1R and conferring pigmentation variation, freckles, as well as skin cancer susceptibility, has been identified in the Eurasians, which suggests a less severe constraint outside of Africa (37-39). Despite this high degree of polymorphisms, we did not observe variation between archaic and present-day people (Table 1). However, our analysis does not cover the MC1R sequences from the Neanderthal exomes (23) as they are missing in the database. Nevertheless, in the other Neanderthal and Denisovan available data, the Neanderthal-specific variant R307G previously identified by PCR amplification of DNA from two geographically distant (Italy and Spain) Neanderthal fossils (55) was not detected (Table 1 ), in agreement with the genotype/phenotype analysis of (21). This loss-of-function mutant was predicted to confer pale skin and red hair. In addition, the weakly-associated fair skin pigmentation V92M (rs2228479) polymorphism exclusively found in Eurasian haplotypes predicted to be introgressed from Neanderthals (54) was not detected (Table 1). However, the V92M substitution is suspected of having emerged after the introgression into anatomically modern humans. All the studies on genes involved in skin pigmentation, including MC1R, suggest that archaic hominins probably exhibited the same pattern of skin and hair color variation as present-day humans $(9,21,55,56)$.

\subsubsection{Neuromedin $U$ receptor 2}

NMUR2 is expressed in the central nervous system where it mediates the inhibitory effects of neuromedin $U$ on food intake and bone formation (57-59). Attempt to associate NMUR2 polymorphisms with obesity (57) or osteoporosis (58) was unsuccessful but revealed the existence of an unusual haplotype including 4 non-synonymous variations (S298T (rs4958535), F315L (rs 1895245), P383L (rs4958532), M388V (rs4958531) ${ }^{1}$ distributed across two separate exons (57). This haplotype is a mixed combination of ancestral (S298, M388V) and not

\footnotetext{
${ }^{1}$ Numbering according to the correct translation start
} 
ancestral (F315L, P383L) alleles. It is found at variable frequency (1-30\%) in worldwide population (Table 1). The four nsSNP were recently identified as candidates for diabetic nephropathy in type 1 diabetes in people with European ancestry (60). Very interestingly, the survey of the archaic genomes shows the presence of the NMUR2 haplotype in Denisova 3, Mez2 and Vi33.15 (Table 1). Despite incomplete coverage of the four positions in the other specimens, the data clearly suggest the presence of the haplotype in the other Neanderthal individuals also. All the variants are located in the TM7 and C-terminus of the receptor where they could alter the interaction with intracellular partners. The NMUR2 haplotype could represent a remarkable example of potential inheritance of a risk of disease from archaic hominins into some present-day humans. The functional and physiological properties of this haplotype certainly deserve further investigations to understand its role in the context of human evolution.

\subsubsection{Oxytocin receptor}

The oxytocin receptor (OTR) is well known for its role in uterine contraction during parturition. It is also associated with social behaviors $(61,62)$. Very interestingly, OTR in all extinct humans carries the A218T (rs4686302) polymorphism in TM5 (tables 1 and 3), which confers favorable sociability traits $(63,64)$, but also represents a potential risk of preterm birth in present-day humans (62). The minor derived allele T218 has been gender-dependently associated to social relationship and emotional empathy, however in opposite way. Indeed, in a study aiming at genotyping a large cohort of Americans for social integration, men carrying T218 were found more prone to social integration and connectedness than women (63). In contrast, a study on Chinese showed a higher emotional empathy in women than in men (64). Nevertheless, in both cases, these traits represent psychological and behavioral processes that have favored social organization and stress-managing during evolution, and it is remarkable to find the associated polymorphism at high frequency in Neanderthal and Denisovan humans. However, as linked to risk of premature birth (62), the A218T variant might have been deleterious in extinct human populations by lowering the number of viable births.

Another derived and rare variant, T360M (rs199856198) located in the C-terminal end of OTR was detected in Denisova 3, and potentially Z4-1514 (Table 1 and S2). Although the mutation contributes to the loss of a putative phosphorylation site, threonine at position 360 is part of a cluster not shown by alanine scanning mutagenesis to be important for beta-arrestin mediated internalization of the receptor (65). Therefore, no deleterious functional consequence is expected for this variant.

\subsubsection{Proteinase-activated receptors PAR4}

Proteinase-activated receptors (PAR1 to PAR4) display a unique mode of activation triggered by proteases such as thrombin and trypsin which, by removing a peptide at the Nterminal extremity, create a new N-terminus that becomes the receptor agonist. They are implicated in cardiovascular and respiratory systems, gastrointestinal tract, visceral pain and inflammation (66). By its action on platelet activation, PAR4 is particularly involved in hemostasis and thrombosis. Very interestingly, the archaic hominins carry the derived variant A120T (rs773902) which has been associated with enhanced platelet aggregation and dense granule release in response to thrombin (67-69), and with stroke risk in Caucasians (69). The 
T120 substitution, located in TM2 of the receptor (Table 2), does not contribute to change in surface expression, receptor cleavage, dimerization and lipid raft localization, but it shows less sensitivity to desensitization and produces higher $\mathrm{Ca}^{++}$mobilization and ERK activation (6769). Since the $120 \mathrm{~T}$ substitution corresponds to the major allele (60\% frequency) in Africa (Table 1), it explains why a higher platelet aggregation and greater $\mathrm{Ca}^{++}$signaling in response to thrombin were primary observed in African-Americans compared to Caucasians, evincing possible ethnic disparities in the outcomes of cardiovascular diseases (67). It is however surprising to find at high frequency in Africa this derived polymorphism shared with Neanderthals and Denisovans, since the African genome is reported to be devoid of DNA from these archaic hominins (15). It is possible that particular harmful environmental conditions necessitating efficient hemostasis may have favored adaptive selection of this more hemostasisefficient polymorphism in both archaic and African populations. But nowadays, carriers of the T120 variant may develop thrombus and stroke, as a maladaptation to modern life.

Another derived variant, D349G (rs201379450) located in the C-terminus of PAR4, is present in Neanderthals only (Table 1). It is found at low frequency $(0.1-0.3 \%)$ in Asian populations today, whereas the worldwide population majorly carries the ancestral allele. No functional or phenotypic information about this polymorphism is available but one might propose that it could contribute to a variability in platelet response and/or sensitivity to cardiovascular treatment specific to Asians.

A derived variant, V125I, specific to Neanderthals, is present in PAR2, the receptor activated by trypsin and involved in blood pressure and inflammation (Table 1 and 2). It is located in TM2 and remains poorly documented (Table 2).

\subsubsection{Pyroglutamylated RFamide peptide receptor}

The QRFP receptor, also known as GPR103, is the receptor for the peptides QRFP-43 and QRFP-26 (26-RFa) shown to stimulate appetite, to induce gonadotropin and insulin release and to regulate bone formation in rodents (70). The physiological role of the receptor in humans is less well documented, although polymorphisms in QRFP/GPR103 have been associated with autoimmune thyroid disease (70). All the Neanderthal and Denisovan QRFP receptors carry the variant R371W (rs79300690) in the C-terminal extremity of the receptor (Table 1 and 2). This polymorphism is found at a higher frequency in present-day Asians (especially East-Asian, $11 \%$ ) than in Europeans (2\%) and Africans/Americans (1\%). No phenotype associated to $\mathrm{R} 371 \mathrm{~W}$ has been reported at this time. It is however interesting to note that mice deficient for QRFP/GPR103 suffer from osteopenia (low bone mineral density) and kyphosis, an excessive curvature of the spine (70). This later deformity was assumed to be a natural anatomy in some Neanderthal individuals (71). It would be therefore of particular interest to investigate the role of the QRFP polymorphism W371 in spine deformation and back pain in present-day humans (more specifically in Asians) that may have inherited this mutation from extinct humans.

\subsubsection{Somatostatin receptor 5}

Somatostatin is an inhibitory hormone that interacts with five receptors (SSTR1 to SSTR5) to decrease the release of gastrointestinal and pancreatic hormones by the digestive system, and of growth hormone (GH), thyroid-stimulating hormone (TSH) and prolactin by the anterior pituitary (72). The somatostatin system is also suspected to be involved in neurodegenerative 
and affective disorders, in part due to heteromerization between SST receptors and dopamine receptors (73). The survey of archaic human genomes reveals the presence of two variants, only in SSTR5 (Table 1). A258V (rs747219171) is located in TM6 and is rarely found in living people. In contrast, P335L (rs169068) in the C-terminal of SSTR5 is a common variant, mainly found (81\% frequency) in East-Asian population (74). P335L has been associated with bipolar affective disorder in British but not in Danish patients (73). In Chinese, the ancestral allele (P335), which is the minor allele in this population, represents a risk of extrahepatic bile duct cancer (75). The ancestral allele has been also associated with shorter survival in American patients with pancreatic cancers (76) while the derived allele (L335) was found expressed in more than $50 \%$ of pancreatic neuroendocrine tumors (77). It seems therefore that both alleles could confer either benefits or risks, depending on populations and diseases, suggesting a possible balancing selection at this position.

Acromegaly is a rare disease characterized by enlargement of bone extremities (face, hands and feet) due to an excess secretion of GH and, subsequently, insulin-like growth factor (IGF1). Although higher levels of GH and IGF-1 have been measured in Italian acromegaly patients carrying the L335, the association with the disease was not significant (78). P335L was also not found associated with acromegaly in unhealthy Latvian individuals (79). The prosecretory effect of the L335 variant on GH secretion may be explained by the fact that SST5 receptors carrying L335 were found less active than P335-carrying SST5R in cellular models (74). Owing that proline plays structural role in proteins and that $\mathrm{P} 335 \mathrm{~L}$ is not conservative, it is possible that the conformational change induced by the proline substitution in the carboxy-end modifies the internalization and desensitization properties of the receptor or the interactions with partners involved in signaling response.

Taken together, the L335 substitution in SSTR5 of archaic hominins may have contributed to the hormonal regulation that shaped the behavioral pattern and the somatic growth of these extinct humans that show different morphological stature and growth development compared to modern humans (80).

\subsubsection{Neuromedin B receptor}

The neuromedin B (or bombesin 1) receptor is involved in the contraction of gastrointestinal and urogenital tracts, satiety and response to stress and fear (81). A role in thyroid disorders is also suggested as it regulates thyroid function by inhibiting TSH release. Neanderthal and Denisova hominins carry the derived variant L390M (rs7453944). This variant corresponds to the minor allele (7-20\% frequency) in present-day populations (Table 1). Since the substitution is conservative and is located at the last position of the receptor, it is not expected to produce functional change. Another variant, G342R (rs889899786) found in Neanderthals hominins is only present in South Asian population at low frequency (0.1\%) today. None of these variants are well documented, but it is interesting to note that both R342 and M390 are present in Neanderthals suggesting a putative haplotype that could be still present in South Asia today (Table1).

\subsubsection{Neuropeptide $Y 4$ receptor}

The neuropeptide Y receptors (Y1, Y2, Y4, Y5 and Y6) are expressed throughout the body and regulate both neuronal and endocrine signaling. They play a role in feeding behavior, mood 
and stress, sleep, gastrointestinal and cardiovascular regulation (82). No coding variants were detected in NPY receptors, except NPY4 (Table 1). Denisova 3 and the Neanderthal individuals (Mez2, Vi33.25, Q56.1) carry the derived variant R236H (rs148351061) located in the $3^{\text {rd }}$ intracellular loop of NPY4R. The ancestral variant R236 is nearly fixed today in humans but the H236 substitution is found in Africa at very low frequency. Other very rare substitutions, R236L and R236P, have been also observed (46) suggesting a hypervariability at this position indicative of either neutral or ongoing selection.

\subsection{Derived variants in Neanderthals}

Many of the variants detected in the Neanderthal specimens are largely represented among the individuals, indicating that they were probably at high frequency in this extinct human population. The overall pattern appears relatively homogeneous with no clear evidence of geographical or timing specificity, except for the Altaï Neanderthal individual that carries three exclusive derived nsSNP, Q270E, A328T (rs78966502) and Y355ter, in the NPFF2, NK1 and motilin receptors, respectively. This is in accordance with the fact that the Altaï specimen (120 ky-old) is found phylogenetically separated from the other more recent Neanderthal ones (37$49 \mathrm{ky}$-old) and is shown to harbor a number of deleterious variants $(43,83)$.

\subsubsection{Motilin receptor}

The Altaï-specific substitution Y355ter in the motilin receptor, corresponds to the insertion of a stop codon just at the end of TM7 leading to premature receptor truncation. This is expected to impair correct expression of the receptor at the cell surface as demonstrated by mutagenesis studies showing that motilin receptor with the C-ter deleted from position 369 is retained intracellularly (84). Given the role of the motilin receptor in gastrointestinal motility, and in the modulation of gastric secretion and emptying, it is likely that carriers of this deleterious mutation may have suffered from gastrointestinal disorders such as gastroparesis (85). Moreover, it has been reported that rodents which only express pseudogenes with premature translation arrests for motilin receptors, are unable to vomit (85). Therefore, although not yet described in present-day people, the mutation Y355ter in the motilin receptor would deserve to be investigated in patients subjected to nausea and ineffective gastric emptying.

\subsubsection{Bombesin receptor 3}

$\mathrm{BB} 3 \mathrm{R}$ is an orphan receptor showing similarity with the receptors for bombesin, neuromedin $\mathrm{B}$ and gastrin-releasing peptide (86). The physiological function of BB3R is not well defined given the absence of a known endogenous ligand. However, knock-out mice models and synthetic molecules have established a role of BBR3 in the regulation of energy expenditure, food intake and body weight. Neanderthals carry the mutation C390G at the C-terminal end of the receptor, leading to the suppression of a putative palmitoylation site (Tables 1 and 3). As this post-translational modification is often reported to be essential for correct processing and membrane targeting of GPCRs as well as for efficient functional coupling, it is possible that the Neanderthal C390G substitution in BB3R induces a loss of activity. A less efficient BB3R is susceptible to modulate energy balance since murine models deleted for BB3R show hyperphagia and reduced energy expenditure, and develop obesity. It is therefore possible that 
the G390 polymorphism may have differentially influenced the energy metabolism of Neanderthal hominins, compared to modern humans.

\subsubsection{Formyl peptide receptor 1}

Formyl peptide receptors (FMLPR1 to FMLPR3) are chemoattractant receptors located at the surface of neutrophils and monocytes, that are involved in the regulation of innate immune response, inflammation, as well as angiogenesis (87). FMLPR1 is characterized by a high number of polymorphisms linked to 15 distinct haplotypes suspected to be differentially associated with resistance or sensibility to infection, depending on populations (88-90). In particular, some FMLPR1 polymorphisms are suspected to play a role in the progression of aggressive periodontitis (AP), a dental infectious disease caused by oral bacterial pathogens and leading to bone destruction and teeth loss $(88,89,91)$. Interestingly, two of these polymorphisms, V101I (rs2070745) located in TM3 and R190W (rs5030880) located in EL2, are identified in the archaic hominins (Table 1). R190W corresponds to the minor allele in present-day populations. V101 corresponds to the common derived allele, however not fixed today since another derived substitution (L101) at this position is also found at high frequency in living people (Table 1). In contrast, the Denisova individual carries the ancestral variant I101 which is rarely found today. Although the replacement of valine by leucine or isoleucine is expected to be functionally neutral, the variability at position 101 may be indicative of an evolutionary mechanism favoring diversity to resist against pathogen infections (3).

Interestingly, Val101 has been found associated with AP in Japanese (88) but not in other African-Americans, Brazilians and Turks (91) and R190 with higher risk of AP in AfricanAmerican population, but not in Brazilian or Turkish populations (91), nor in Japanese (88). Comparative functional studies of the substitutions R190 and W190 in the 2nd extracellular loop of FLMPR1 show a variable selectivity of the receptor towards a diversity of formyl and viral peptides, likely contributing to a differential ability to respond to bacterial or viral infections $(89,92)$. Finding polymorphisms in FMLPR1 presenting both risk and protective effect against aggressive periodontitis in the Neanderthal and Denisovan individuals likely reflects a variability in predisposition to infection within archaic hominins, as it is observed in modern people today.

\subsubsection{Neuropeptide FF receptors}

Neuropeptide FF receptors, NPFF1 and NPFF2, firstly characterized for their opioidmodulating properties in pain, tolerance and dependence to morphine, are also involved in the regulation of arterial blood pressure and heart rate, the reproductive axis and food intake (93, 94).

The main characterized effect of NPFF1 receptor in mammals is the inhibition of the release of gonadotropin hormones (94). Neanderthal individuals carry the NPFF1 receptor derived variant R347S (rs113487866) found at around 5\% frequency in worldwide population today (Table 1). This nsSNP was identified in patients with gonadotropin-releasing hormonedependent pubertal disorders but was not found associated with the disease (95). Located in the C-terminus of the receptor, the mutation introduces a putative phosphorylation sites that could influence the capacity of internalization or desensitization of the receptor. 
Another variant, T375I, located in the C-ter of the NPFF2 receptor, is exclusively found in the genome of Neanderthals. This amino acid substitution contributes to the loss of a phosphorylation site that has been involved in the desensitization but not the internalization of the receptor (96). This variant is not described in living people but a coding variation at the same position, T475S (rs190387826), maintaining the phosphorylation site, is found at low frequency in Africans. Other variants shared by the Denisova and Neanderthal individuals (G28E, long form of the receptor) or specific to the Altaï Neanderthal individual (Q270E) have not been identified in living people. The impact of these mutations on receptor function is unknown.

\subsubsection{Tachykinin receptors}

Neurokinin receptors (NK1R to NK3R) are receptors for tachykinins, a family of amidated peptides with a large spectrum of actions on gastrointestinal, respiratory and urogenital tracts, on skin, and on nervous and immune systems (97).

The substitutions A328T (rs78966502) located in the intracellular domains of the NK1R is found in the Altaï Neanderthal individual. It is a low frequency allele $(0.2 \%)$ nowadays in Africa. The impact of these mutation on receptor function is not reported, but the introduction of a threonine residue in the $\mathrm{C}$-ter of the receptor may however create a phosphorylation site susceptible to play a role in receptor desensitization.

NK2R mediates smooth muscle contraction in the gastrointestinal, pulmonary and urinary tracts and is involved in irritable bowel syndrome, asthma and urinary disorders. In the airway track, NK2R participates in cough reflex in response to irritant stimuli. The NK2 receptor of Neanderthal hominins displays the derived variant R375H (rs2229170) corresponding to the nowadays minor allele found at $2 \%$ in African population and at $20 \%$ frequency in others. This polymorphism has been studied in patients suffering from chronic cough but was not found associated with enhanced cough sensitivity $(98,99)$. The variant is located in the C-terminus of the receptor and does not change the pharmacological property of the receptor regarding intracellular calcium response (100).

\subsubsection{Endothelin B receptor}

Endothelins are potent vasoconstrictor peptides that interact with two receptors, $\mathrm{ET}_{\mathrm{A}}$ and $\mathrm{ET}_{\mathrm{B}}$ (101). $\mathrm{ET}_{\mathrm{B}}$ receptor is primarily located in endothelial cells, with a high expression in brain. Its role on cardiovascular system is complex as it mediates both constrictor and dilator effects via direct or indirect mechanisms. Interestingly, the gene coding for $\mathrm{ET}_{\mathrm{B}}$ receptor shows evidence of strong selection for adaptation to high altitude hypoxia in Ethiopian highlanders (102). Two Neanderthal individuals (Altaï and potentially Q56-1) carry the derived variant $\mathrm{T} 244 \mathrm{M}$ (rs5350). This variant is found today in the African population at a low frequency (1\%), while the worldwide population carries the ancestral polymorphism. As located in the extracellular loop EL2 shown to be involved in the selective binding of endothelin 3 to $\mathrm{ET}_{\mathrm{B}}$ (103), the mutation may modulate receptor activity. Based on genetically modified mouse models, it has been proposed that a lower activity of $\mathrm{ET}_{\mathrm{B}}$ receptor favors adaptation to high altitude (102). It would be therefore interesting to investigate whether the M244 substitution in $\mathrm{ET}_{\mathrm{B}}$ receptor could have played a role in adaptation to high altitude in some humans and Neanderthal population. 


\subsection{Derived variants in Denisovans}

In contrast to Neanderthals, the two Denisovan individuals show divergence as not sharing variant that could be attributed to the Denisovan lineage, except for the galanin receptor (Table 1). This agrees with genomic data showing that the oldest Denisovan specimen 2 is distantly related to the Denisovan specimen 3 (11) and that the Denisovan specimen 3 contains a small amount of Neanderthal DNA in his genome (104). Therefore, given the low-coverage of specimen 2 and in the absence of other Denisovan genomes, it is not possible to conclude whether the 13 exclusive variants found in the Denisovan specimen 3, were common to Denisovan hominins or unique to the specimen 3. Half of the Denisovan variants are present today at low or very low frequency in particular populations, the other half being not characterized (Table 1). In consequence there is poor information on these variants (Table 2). The substitution T153M (rs754545858) in the bombesin 1 receptor may lead to the suppression of a putative phosphorylation site in the 2nd intracellular loop of the receptor and could therefore contribute to modulate receptor desensitization. The substitution D16A (rs140696405) located in the $\mathrm{N}$-terminal domain of the bradykinin 2 receptor is not expected to have a functional incidence since the aspartate residues in the rat B2 receptor was not found involved in the binding of bradykinin (105). Three variants, L16I (rs761342288), A35S and A405S were identified in the melanin-concentrating hormone receptor 1 (MCHR1) (Table 1). This receptor is involved in food intake, energy expenditure, anxiety and stress (106). Some polymorphisms in MCHR1 have been inconsistently associated with obesity $(106,107)$ or leanness (108), but they do not include the variants identified in Denisova 3.

\subsection{Ancestral variants in archaic hominins}

There are only three receptors for which the archaic hominins retain an ancestral variant when the derived allele is fixed (100\% frequency), or nearly fixed (90-100\% frequency), in modern humans (Table 1, Figure 2). They include the melanin-concentrating hormone receptor $\mathrm{MCH} 2 \mathrm{R}$, the Mu-opioid (MOP) receptor and the vasopressin (V1B) receptor. Besides, the Neuropeptide $S$ receptor (NPSR) also shows an ancestral allele of potential interest.

\subsubsection{Mu-opioid receptor}

Opioid receptors (MOP, DOP, KOP) are neuronal receptors well known for their role in pain inhibition and rewarding processes underlying drug addiction (109). But they are also involved in the regulation of many other physiological functions relative to stress, mood and immune system. A number of studies have focused on the association of opioid receptor polymorphisms with substance abuse or pain sensitivity without giving consistent results $(110,111)$. Compared to the other opioid receptors, MOP is the most highly polymorphic. It displays 3 times more nsSNP and many isoforms, truncated or with variable $\mathrm{N}$ - and $\mathrm{C}$ - terminal extremities, that are produced by alternative splicing and/or upstream translational initiation (112). It is thus assumed that the MOP receptor is under adaptive selection (113). MOP is the main target of opiate analgesic drugs such as morphine for alleviating pain. It is also the principal opioid 
receptor mediating the rewarding processes responsible for addiction to both opioid (heroin) and non-opioid (ethanol, cocaine, cannabis, tobacco) drugs of abuse $(111,112)$.

All the Neanderthal and Denisovan sequences carry the mutation A6V in the N-terminal domain of the receptor, which corresponds to the ancestral variant rs1799972 (Tables 1 and 3). Today, this polymorphism is highly frequent in African and Afro-American (20-26\%) and in Northern Indian populations (110). Although the incidence of the A6V polymorphism on physiological functions is unknown, a tendency to more frequently observe the A6V polymorphism in cocaine, alcohol and tobacco consumers has been reported (111). In cellular systems, there is no difference in expression and binding affinity between MOP receptor with the A6 or V6 substitution but, depending on study, an increased efficacy of the synthetic peptide DAMGO has been observed (110). The involvement of the A6V polymorphism in differential response to endogenous opioid peptides certainly merits to be further investigated for understanding the inter-individual variability in pain sensitivity and in efficacy of opioid treatment (110)..

All the Denisova and Neanderthal individuals also carry another ancestral variant that introduces a stop codon at position 26 (Q26ter, rs17174638) (Table 1). This leads to a premature arrest of the protein translation susceptible to be deleterious. However, this stop codon is only present in the long N-terminal isoforms of MOP generated by the use of an upstream ATG codon (114) or arising from alternative splicing (112). These long N-terminal MOP isoforms are described to have no binding activity and low functional activity (112). They behave as negative regulators of the canonical MOP receptor isoforms by promoting their downregulation (114). Therefore, the stop insertion is not ultimately expected to be highly deleterious, but instead should be advantageous by favoring the expression of the canonical MOP receptor isoforms. Today, this loss-of function variant is present at $12 \%$ frequency in the African population. The biological impact of this variant is not known.

In conclusion, compared to the archaic humans that carries MOP ancestral variants with partial or total functional deficit, present-day modern humans have therefore acquired more variability in MOP receptor isoforms, with gain of biological activity or regulatory functions, potentially giving them an evolutionary advantage that remains to be elucidated.

Beside MOP, two variants A7S (rs375635141) and A285V (rs1011648037) were also detected in the opioid receptor-like (ORL1)/nociceptin receptor (NOP), the fourth member of the opioid receptor family $(115,116)$. This receptor plays a complex modulatory role on pain and stress, is involved in orexigenic behavior and cognitive processes, and attenuates drug rewarding processes (117). Interestingly, while the Neanderthal individuals carry the ancestral (A7) and derived (A285) alleles fixed in humans today, the Denisova 3 shows the reverse profile, suggesting a closer relationship between Neanderthals and modern humans for this receptor.

\subsubsection{Vasopressin receptor}

The arginine-vasopressin V1B receptor is mainly expressed in the pituitary where it stimulates, in synergy with corticotropin-release hormone $(\mathrm{CRH})$, the release of the adrenocorticotropic hormone (ACTH) in response to stress. By its action on the hypothalamicpituitary-adrenal HPA axis, V1B is involved in psychological/behavioral traits such as mood, anxiety, social interaction and aggressiveness (118). It plays also a role in metabolism by 
regulating the secretion of the pancreatic hormones insulin and glucagon in favor of energy storage. Both of these effects represent adaptive responses to stress and environmental changes, which supports the observation that the V1B gene was subjected to selection during human evolution (118). The gene has been associated with mood- and stress- related disorders, showing a genetic variability that depends on ethnicity and reflecting the diversity of behavioral traits and strategies observed in human individuals $(118,119)$. The V1B receptors from all the Neanderthals and Denisova carry the ancestral variant G191R (rs33990840), found in presentday population with a frequency of $13 \%$ in Africans, $4-5 \%$ in Europeans, Americans and SouthAsians and $1 \%$ in East-Asians (Table 1). Interestingly, a study on 660 Ukrainian family trios showed that the present-day major variant G191 is associated with a risk of high-depression syndrome and suicide attempt (119). G191R is located in the $2^{\text {nd }}$ extracellular loop of the V1B receptor (Table 2) close to residues involved in agonist binding (118). The amino acid change in the binding pocket is expected to influence the affinity and/or the activity of the receptor. Since mice lacking the V1B receptor or administrated with an antagonist show decreased anxiety and aggressiveness (118), it is possible that a less functional activity of the R191carrying V1B receptor explains the protective effect of the minor variant. Presence of the advantageous substitution R191 in the V1B receptor of the Neanderthals and Denisovans may have protected them from anxiety and depressive disorder.

\subsubsection{Melanin-concentrating hormone receptor 2}

MCHR2 is one of the two receptors recognized by the melanin-concentrating hormone (MCH), a 19 amino acid-length brain neuropeptide involved in feeding, energy metabolism and emotional state (106). The receptor is only present in the central nervous system of higher order mammals. As not expressed in rodents it has not been extensively studied and, consequently, its physiological role is not well defined. In human genetics, the MCH2R locus is suspected to be associated with risk of bipolar affective disorder in male patients (120) and to have a moderate effect on children feeding behavior (121). All the Neanderthal and Denisovan genomes carry the ancestral variant A324V (rs201718043) (Table 1). In living humans, alanine is fixed but substitution by valine, glycine and glutamic acid have been rarely observed indicating possible variability at this position. The coding variation occurs at the C-terminus of the receptor (Table 2). Exchange between alanine and valine is not expected to have a functional impact at this position.

\subsubsection{Neuropeptide $S$ receptor}

The receptor for Neuropeptide S (NPSR), previously known as GPRA (G-protein coupled receptor for asthma susceptibility) was found associated with asthma pathogenesis before its endogenous ligand being identified (122). NPSR is expressed in lung, gut and immune cells in addition to brain. It plays a role in inflammation, nociception, and promotes arousal and anxiolytic-like effects $(122,123)$. Polymorphisms in NPSR have been involved in predisposition to chronic inflammatory diseases such as asthma, rheumatoid arthritis and bowel inflammatory disorder $(122,124)$, anxiety and psychiatric disorders $(123,125,126)$ and colonic transit and visceral pain (127). Interestingly, two of these polymorphisms, the ancestral variant N107I (rs324981) and the derived variant Q344R (rs6972158), are present in the coding sequence of NPSR in all Neanderthal and Denisova hominins (see description below). These 
polymorphisms are commonly found in living people today, however with differential ethnic frequency in particular for Q344R (Table 1). In addition, two other derived variants, I102V specific to Neanderthals and W201G specific to Denisova, were also evidenced. They have not been described in living people, but rare variants I102T (rs542257541) and W201ter (rs776453644) are respectively found nowadays indicating a variability at this amino acid position.

The ancestral variant N107I, located in the $2^{\text {nd }}$ extracellular loop (Table 2) has been characterized as a gain-of-function variant contributing to higher expression of the receptor at the cell surface and to higher receptor efficacy $(123,128)$. This polymorphism is well documented as it may participate to diverse inflammatory pathologies. The mutant is part of risk haplotypes for asthma and high serum immunoglobulin E (122), allergic rhinitis (129), inflammatory bowel disease (124). Interestingly, N107I has been also associated with anxiety and panic disorder, which is consistent with the fact that comorbidity between these pathologies and asthma has been evidenced (126). However, the data are not always concordant, depending on ethnic origin and sex. One haplotype including N107I was found associated with panic disorder in different European cohorts (126). N107I was also sex-specifically associated with this syndrome in males from Japanese ancestry (130) and females from German ancestry (125). In this later study, the variant was also associated with anxiety and increased signs of stress in behavioral avoidance test in females. Interestingly, the MRI functional imaging experiments in response to emotional stimuli also showed allele-dependent activation of different cerebral areas: regions involved in arousal for I107 carriers, regions involved in the attenuation of fearrelated emotions for N107 carriers. This suggests that the gain-of-function mutant N107I may be responsible for an increased arousal response that contributes to excessive anxiety, with risk of panic disorder (125). In support, N107I has been found associated with sleep and circadian phenotypes (131), increased attention-deficit/hyperactivity disorder and male-specific impulsivity (132). It has also been reported that carriers of N107I are also less susceptible to develop schizophrenia (130,133). Given that the ancestral variant I107 of NPSR confers higher receptor activity, increased arousal and motor restlessness, and higher inflammatory response, it is possible that this polymorphism was adapted for people living in hostile environment. It may have been advantageous to protect from exposition to pathogens, to fight against wild animals or enemies, or for hunting. Now that struggle for survival is less important and that contact with pathogens is less frequent, carriers of the N107I may display maladapted excessive response that contribute to chronic inflammatory disease and anxiety-related disorder.

The derived variant Q344R has been associated, together with N107I, with accelerated colonic transit (127). Q344R is only found in the C-terminus of the splice variant corresponding to NPSR isoform A (Table 2). Although not well characterized, this variant does not display functional change (124). It is interesting to note that both archaic hominins and modern humans carry at position 344 a derived variant different from that of primates (Table 1), and that the archaic substitution R344 is a common variant today. This suggests that this position may be still under selection. Because of the presence of N107I and Q344R in NPSR from Neanderthal and Denisova, it is possible that archaic hominins were susceptible to respiratory and gastrointestinal disorders as observed today. But, more likely, the presence of these ancestral polymorphisms in living humans, in particular N107I displaying a higher activity, may 
contribute to non-adapted response towards modern allergens which predisposes to allergies and gut inflammation, two common major health issues nowadays.

\section{Conclusion}

Global genome analyses revealed that archaic genomes have probably influenced the pigmentation, derm physiology, immunological response, stature, sleep, mood and addictive behavior of present-day humans $(20,21)$. By specifically analyzing the coding regions in extinct hominins genomes, (23) observed that Neanderthals and Denisovans mostly differ from modern humans in genes involved in metabolism, cardiovascular functions and morphology, whereas modern human variations are found in the exons of genes associated with pigmentation, psychiatric disorder and behavior related to hyperactivity and aggressiveness. However to date, the functional impact of archaic polymorphisms in proteins has been described in only few cases, including the variant F282S in the receptor MARCO (macrophage receptor with collagenous structure) linked to susceptibility to tuberculosis disease (134), the substitution V381A in the aryl hydrocarbon receptor (AHR) contributing to differential sensitivity towards environmental pollutants (135), and the variant A429V, which by modifying the enzyme stability of the adenylosuccinate lyase (ADSL), is susceptible to cause neurological outcomes (136). In all the three cases, the missense variant corresponds to the ancestral allele in archaic hominins and the derived variant in modern humans.

Here, by scrutinizing differences at the amino acid level between archaic and modern human peptide GPCRs and by investigating the functional changes and phenotypes associated with these polymorphisms, we provide the description of a set of discrete traits associated with archaic polymorphisms that come into support to those deduced from global genomic studies. Our survey suggests that Neanderthal and Denisovan hominins were likely prone to lower risk of obesity (I103 in MC4R), to enhanced platelet aggregation in response to thrombin (T120 in PAR4), variable response to infection (I107 and R344 in NPSR, V101 and W190 in FMLPR1), favorable sociability (T218 in OTR), less anxiety and aggressiveness (R191 in V1bR) and increased arousal (I107 in NPSR). A variant involved in growth (L335 in SST5R) is also detected. While some archaic variants were likely advantageous in the past, they might be responsible for maladaptive disorders today in the context of modern life and/or specific regional distribution. Indeed, the archaic derived variants associated with an increased activity of the immune system (R344 in NPSR and W190 in FMLPR1) and hypercoagulation (T120 in PAR4) may predispose to respiratory and gastrointestinal inflammatory diseases and to cardiovascular outcomes, respectively. P335L in SST5R is associated with risk of bipolar affective disorder. Very interestingly, NMUR2 harbor three different haplotypes discriminating primates, archaic hominins and present-day humans. The archaic haplotype which represents the minor allele in worldwide populations is susceptible to confer risk of diabetic nephropathy in type 1 diabetes in present-day Europeans. Finally, the ancestral variant V6 in MOP may be associated today with risk of addictive behavior and the ancestral variant I107 in NPSR also linked to circadian rhythm may influence anxiety and psychiatric disorders (hyperactivity and impulsivity) depending on gender and ethnic ancestry.

Beside, a number of the derived variants identified in the archaic genomes are unknown or not yet fully characterized (Table 1). It would certainly be of main interest to investigate the 
functional properties of these variants and to carry on genome wide association analyses and population studies. For example, the polymorphism R371W might be explored for skeleton deformation and the putative haplotype in BB1R for thyroid disorder.

Paying attention to the pharmacological properties of some of the archaic variants described in this study may reveal currently uncharacterized particular phenotype or pathology related to rare, or to geographical restricted, polymorphisms. Taking into account archaic GPCR variants may also be worth considering in the perspective of pharmacogenomics and personalized medicine, especially since natural genetic variations in GPCRs have been involved in the variability of therapeutic efficacy between individuals and ethnic groups (26). For example, some polymorphisms in the MOP receptor that have no particular consequence in normal physiological condition, affect the response to analgesics and can cause severe respiratory depression. Therefore, even if an archaic GPCR polymorphism has no direct impact on phenotypical or physiological traits, it might show altered response to drug treatment. Finally, making accessible to the reader some archaic information about her/his favorite GPCR, may open the way to new experimental investigations aiming at understanding receptor functional properties or phenotypic association.

\section{Acknowledgements}

We are very grateful to L. Moulédous (CRCA, Toulouse) and JS Saulnier-Blache (I2MC, Toulouse) for helpful discussion and comments during the preparation of the manuscript. The work was supported by CNRS (PEPS blanc 2016 and DefiXlife 2018-19).

\section{Author contribution statement}

CM designed and performed the study, wrote the manuscript. XM and GR supported a part of the computational analyses. 


\section{References}

1. Balaresque P, King TE. Human phenotypic diversity: an evolutionary perspective. Curr Top Dev Biol. 2016;119:349-90.

2. Jeong C, Di Rienzo A. Adaptations to local environments in modern human populations. Curr Opin Genet Dev. 2014;29:1-8.

3. Karlsson EK, Kwiatkowski DP, Sabeti PC. Natural selection and infectious disease in human populations. Nat Rev Genet. 2014;15(6):379-93.

4. Dannemann M, Racimo F. Something old, something borrowed: admixture and adaptation in human evolution. Curr Opin Genet Dev. 2018;53:1-8.

5. Racimo F, Sankararaman S, Nielsen R, Huerta-Sanchez E. Evidence for archaic adaptive introgression in humans. Nat Rev Genet. 2015;16(6):359-71.

6. Green RE, Krause J, Briggs AW, Maricic T, Stenzel U, Kircher M, et al. A draft sequence of the Neandertal genome. Science. 2010;328(5979):710-22.

7. $\quad$ Prufer K, Racimo F, Patterson N, Jay F, Sankararaman S, Sawyer S, et al. The complete genome sequence of a Neanderthal from the Altai Mountains. Nature. 2014;505(7481):43-9.

8. Prufer K, de Filippo C, Grote S, Mafessoni F, Korlevic P, Hajdinjak M, et al. A highcoverage Neandertal genome from Vindija Cave in Croatia. Science. 2017;358(6363):655-8.

9. Meyer M, Kircher M, Gansauge MT, Li H, Racimo F, Mallick S, et al. A high-coverage genome sequence from an archaic Denisovan individual. Science. 2012;338(6104):222-6.

10. Reich D, Green RE, Kircher M, Krause J, Patterson N, Durand EY, et al. Genetic history of an archaic hominin group from Denisova Cave in Siberia. Nature. 2010;468(7327):1053-60.

11. Slon V, Viola B, Renaud G, Gansauge MT, Benazzi S, Sawyer S, et al. A fourth Denisovan individual. Sci Adv. 2017;3(7):e1700186.

12. Sawyer S, Renaud G, Viola B, Hublin JJ, Gansauge MT, Shunkov MV, et al. Nuclear and mitochondrial DNA sequences from two Denisovan individuals. Proc Natl Acad Sci U S A. 2015;112(51):15696-700.

13. Galway-Witham J, Stringer C. How did Homo sapiens evolve? Science. 2018;360(6395):1296-8.

14. Lalueza-Fox C, Gilbert MT. Paleogenomics of archaic hominins. Curr Biol. 2011;21(24):R1002-9.

15. Paabo S. The human condition-a molecular approach. Cell. 2014;157(1):216-26.

16. Fu Q, Posth C, Hajdinjak M, Petr M, Mallick S, Fernandes D, et al. The genetic history of Ice Age Europe. Nature. 2016;534(7606):200-5.

17. Vattathil S, Akey JM. Small amounts of archaic admixture provide big insights into human history. Cell. 2015;163(2):281-4.

18. Slatkin M, Racimo F. Ancient DNA and human history. Proc Natl Acad Sci U S A. 2016;113(23):6380-7.

19. Sankararaman S, Mallick S, Dannemann M, Prufer K, Kelso J, Paabo S, et al. The genomic landscape of Neanderthal ancestry in present-day humans. Nature. 2014;507(7492):354-7.

20. Simonti CN, Vernot B, Bastarache L, Bottinger E, Carrell DS, Chisholm RL, et al. The phenotypic legacy of admixture between modern humans and Neandertals. Science. 2016;351(6274):737-41.

21. Dannemann M, Kelso J. The contribution of Neanderthals to phenotypic variation in modern humans. Am J Hum Genet. 2017;101(4):578-89.

22. Krause J, Paabo S. Genetic time travel. Genetics. 2016;203(1):9-12.

23. Castellano S, Parra G, Sanchez-Quinto FA, Racimo F, Kuhlwilm M, Kircher M, et al. Patterns of coding variation in the complete exomes of three Neandertals. Proc Natl Acad Sci U S A. 2014;111(18):6666-71. 
24. Sullivan AP, de Manuel M, Marques-Bonet T, Perry GH. An evolutionary medicine perspective on Neandertal extinction. Journal of human evolution. 2017;108:62-71.

25. Hughes GM, Teeling EC, Higgins DG. Loss of olfactory receptor function in hominin evolution. PLoS One. 2014;9(1):e84714.

26. Hauser AS, Chavali S, Masuho I, Jahn LJ, Martemyanov KA, Gloriam DE, et al. Pharmacogenomics of GPCR drug targets. Cell. 2017.

27. Kim HR, Duc NM, Chung KY. Comprehensive Analysis of non-synonymous natural variants of G Protein-Coupled Receptors. Biomol Ther (Seoul). 2017.

28. Wahlestedt C, Brookes AJ, Mottagui-Tabar S. Lower rate of genomic variation identified in the trans-membrane domain of monoamine sub-class of Human G-Protein Coupled Receptors: the Human GPCR-DB Database. BMC Genomics. 2004;5:91.

29. Schoneberg T, Hofreiter M, Schulz A, Rompler H. Learning from the past: evolution of GPCR functions. Trends Pharmacol Sci. 2007;28(3):117-21.

30. Fredriksson R, Lagerstrom MC, Lundin LG, Schioth HB. The G-protein-coupled receptors in the human genome form five main families. Phylogenetic analysis, paralogon groups, and fingerprints. Mol Pharmacol. 2003;63(6):1256-72.

31. Gether U. Uncovering molecular mechanisms involved in activation of $\mathrm{G}$ proteincoupled receptors. Endocr Rev. 2000;21(1):90-113.

32. Strotmann R, Schrock K, Boselt I, Staubert C, Russ A, Schoneberg T. Evolution of GPCR: change and continuity. Mol Cell Endocrinol. 2011;331(2):170-8.

33. Insel PA, Tang CM, Hahntow I, Michel MC. Impact of GPCRs in clinical medicine: monogenic diseases, genetic variants and drug targets. Biochim Biophys Acta. 2007;1768(4):994-1005.

34. Schoneberg T, Schulz A, Biebermann H, Hermsdorf T, Rompler H, Sangkuhl K. Mutant G-protein-coupled receptors as a cause of human diseases. Pharmacol Ther. 2004;104(3):173206.

35. Vassart G, Costagliola S. G protein-coupled receptors: mutations and endocrine diseases. Nat Rev Endocrinol. 2011;7(6):362-72.

36. Pierron D, Cortes NG, Letellier T, Grossman LI. Current relaxation of selection on the human genome: tolerance of deleterious mutations on olfactory receptors. Mol Phylogenet Evol. 2013;66(2):558-64.

37. Beaumont KA, Wong SS, Ainger SA, Liu YY, Patel MP, Millhauser GL, et al. Melanocortin $\mathrm{MC}(1)$ receptor in human genetics and model systems. Eur J Pharmacol. 2011;660(1):103-10.

38. Dessinioti C, Antoniou C, Katsambas A, Stratigos AJ. Melanocortin 1 receptor variants: functional role and pigmentary associations. Photochem Photobiol. 2011;87(5):978-87.

39. Harding RM, Healy E, Ray AJ, Ellis NS, Flanagan N, Todd C, et al. Evidence for variable selective pressures at MC1R. Am J Hum Genet. 2000;66(4):1351-61.

40. Razafindrazaka H, Monnereau A, Razafindrazaka D, Tonasso L, Schiavinato S, Rakotoarisoa JA, et al. Genetic admixture and flavor preferences: androstenone sensitivity in Malagasy populations. Hum Biol. 2015;87(1):59-70.

41. Kent WJ, Sugnet CW, Furey TS, Roskin KM, Pringle TH, Zahler AM, et al. The human genome browser at UCSC. Genome research. 2002;12(6):996-1006.

42. Cappellini E, Prohaska A, Racimo F, Welker F, Pedersen MW, Allentoft ME, et al. Ancient biomolecules and evolutionary inference. Annu Rev Biochem. 2018;87:1029-60.

43. Hajdinjak M, Fu Q, Hubner A, Petr M, Mafessoni F, Grote S, et al. Reconstructing the genetic history of late Neanderthals. Nature. 2018;555(7698):652-6.

44. Li H, Handsaker B, Wysoker A, Fennell T, Ruan J, Homer N, et al. The sequence alignment/map format and SAMtools. Bioinformatics. 2009;25(16):2078-9. 
45. Aken BL, Achuthan P, Akanni W, Amode MR, Bernsdorff F, Bhai J, et al. Ensembl 2017. Nucleic Acids Res. 2017;45(D1):D635-D42.

46. Lek M, Karczewski KJ, Minikel EV, Samocha KE, Banks E, Fennell T, et al. Analysis of protein-coding genetic variation in 60,706 humans. Nature. 2016;536(7616):285-91.

47. Isberg V, Mordalski S, Munk C, Rataj K, Harpsoe K, Hauser AS, et al. GPCRdb: an information system for $G$ protein-coupled receptors. Nucleic Acids Res. 2016;44(D1):D35664.

48. Gantz I, Fong TM. The melanocortin system. Am J Physiol Endocrinol Metab. 2003;284(3):E468-74.

49. Hughes DA, Hinney A, Brumm H, Wermter AK, Biebermann H, Hebebrand J, et al. Increased constraints on MC4R during primate and human evolution. Hum Genet. 2009;124(6):633-47.

50. Loos RJ. The genetic epidemiology of melanocortin 4 receptor variants. Eur J Pharmacol. 2011;660(1):156-64.

51. Staubert C, Tarnow P, Brumm H, Pitra C, Gudermann T, Gruters A, et al. Evolutionary aspects in evaluating mutations in the melanocortin 4 receptor. Endocrinology. 2007;148(10):4642-8.

52. Tao YX. The melanocortin-4 receptor: physiology, pharmacology, and pathophysiology. Endocr Rev. 2010;31(4):506-43.

53. Bellisari A. Evolutionary origins of obesity. Obes Rev. 2008;9(2):165-80.

54. Ding Q, Hu Y, Xu S, Wang CC, Li H, Zhang R, et al. Neanderthal origin of the haplotypes carrying the functional variant Val92Met in the MC1R in modern humans. Mol Biol Evol. 2014;31(8):1994-2003.

55. Lalueza-Fox C, Rompler H, Caramelli D, Staubert C, Catalano G, Hughes D, et al. A melanocortin 1 receptor allele suggests varying pigmentation among Neanderthals. Science. 2007;318(5855):1453-5.

56. Cerqueira CC, Paixao-Cortes VR, Zambra FM, Salzano FM, Hunemeier T, Bortolini MC. Predicting Homo pigmentation phenotype through genomic data: from Neanderthal to James Watson. Am J Hum Biol. 2012;24(5):705-9.

57. Bhattacharyya S, Luan J, Farooqi IS, Keogh J, Montague C, Brennand J, et al. Studies of the neuromedin U-2 receptor gene in human obesity: evidence for the existence of two ancestral forms of the receptor. J Endocrinol. 2004;183(1):115-20.

58. Chun EH, Kim H, Suh CS, Kim JH, Kim DY, Kim JG. Polymorphisms in neuropeptide genes and bone mineral density in Korean postmenopausal women. Menopause. 2015;22(11):1256-63.

59. Martinez VG, O'Driscoll L. Neuromedin U: a multifunctional neuropeptide with pleiotropic roles. Clin Chem. 2015;61(3):471-82.

60. Lee YH, Song GG. Genome-wide pathway analysis for diabetic nephropathy in type 1 diabetes. Endocr Res. 2016;41(1):21-7.

61. Aspe-Sanchez M, Moreno M, Rivera MI, Rossi A, Ewer J. Oxytocin and vasopressin receptor gene polymorphisms: role in social and psychiatric traits. Front Neurosci. 2015;9:510.

62. Kim J, Stirling KJ, Cooper ME, Ascoli M, Momany AM, McDonald EL, et al. Sequence variants in oxytocin pathway genes and preterm birth: a candidate gene association study. BMC Med Genet. 2013;14:77.

63. Chang SC, Glymour MM, Rewak M, Cornelis MC, Walter S, Koenen KC, et al. Are genetic variations in OXTR, AVPR1A, and CD38 genes important to social integration? Results from two large U.S. cohorts. Psychoneuroendocrinology. 2014;39:257-68.

64. $\mathrm{Wu} \mathrm{N}, \mathrm{Li} \mathrm{Z}, \mathrm{Su} \mathrm{Y}$. The association between oxytocin receptor gene polymorphism (OXTR) and trait empathy. J Affect Disord. 2012;138(3):468-72. 
65. Oakley RH, Laporte SA, Holt JA, Barak LS, Caron MG. Molecular determinants underlying the formation of stable intracellular $\mathrm{G}$ protein-coupled receptor-beta-arrestin complexes after receptor endocytosis*. J Biol Chem. 2001;276(22):19452-60.

66. Adams MN, Ramachandran R, Yau MK, Suen JY, Fairlie DP, Hollenberg MD, et al. Structure, function and pathophysiology of protease activated receptors. Pharmacol Ther. 2011;130(3):248-82.

67. Edelstein LC, Simon LM, Lindsay CR, Kong X, Teruel-Montoya R, Tourdot BE, et al. Common variants in the human platelet PAR4 thrombin receptor alter platelet function and differ by race. Blood. 2014;124(23):3450-8.

68. Morikawa Y, Kato H, Kashiwagi H, Nishiura N, Akuta K, Honda S, et al. Proteaseactivated receptor-4 (PAR4) variant influences on platelet reactivity induced by PAR4activating peptide through altered $\mathrm{Ca}(2+)$ mobilization and ERK phosphorylation in healthy Japanese subjects. Thromb Res. 2018;162:44-52.

69. Whitley MJ, Henke DM, Ghazi A, Nieman M, Stoller M, Simon LM, et al. The proteaseactivated receptor 4 Ala120Thr variant alters platelet responsiveness to low-dose thrombin and protease-activated receptor 4 desensitization, and is blocked by non-competitive P2Y12 inhibition. J Thromb Haemost. 2018;16(12):2501-14.

70. Leprince J, Bagnol D, Bureau R, Fukusumi S, Granata R, Hinuma S, et al. The ArgPhe-amide peptide 26RFa/glutamine RF-amide peptide and its receptor: IUPHAR Review 24. Br J Pharmacol. 2017;174(20):3573-607.

71. Weber J, Pusch CM. The lumbar spine in Neanderthals shows natural kyphosis. Eur Spine J. 2008;17 Suppl 2:S327-30.

72. Patel YC. Somatostatin and its receptor family. Front Neuroendocrinol. 1999;20(3):15798.

73. Nyegaard M, Borglum AD, Bruun TG, Collier DA, Russ C, Mors O, et al. Novel polymorphisms in the somatostatin receptor 5 (SSTR5) gene associated with bipolar affective disorder. Mol Psychiatry. 2002;7(7):745-54.

74. Zhou G, Gingras MC, Liu SH, Li D, Li Z, Catania RL, et al. The hypofunctional effect of P335L single nucleotide polymorphism on SSTR5 function. World J Surg. 2011;35(8):171524.

75. Xu HL, Hsing AW, Koshiol J, Chu LW, Cheng JR, Gao J, et al. Variants in motilin, somatostatin and their receptor genes and risk of biliary tract cancers and stones in Shanghai, China. Meta Gene. 2014;2:418-26.

76. Li D, Tanaka M, Brunicardi FC, Fisher WE, Gibbs RA, Gingras MC. Association between somatostatin receptor 5 gene polymorphisms and pancreatic cancer risk and survival. Cancer. 2011;117(13):2863-72.

77. Zhou G, Liu SH, Shahi KM, Wang H, Duan X, Lin X, et al. Negative regulation of pancreatic and duodenal homeobox-1 by somatostatin receptor subtype 5. Mol Endocrinol. 2012;26(7):1225-34.

78. Ciganoka D, Balcere I, Kapa I, Peculis R, Valtere A, Nikitina-Zake L, et al. Identification of somatostatin receptor type 5 gene polymorphisms associated with acromegaly. Eur J Endocrinol. 2011;165(4):517-25.

79. Lania A, Mantovani G, Spada A. Genetic abnormalities of somatostatin receptors in pituitary tumors. Mol Cell Endocrinol. 2008;286(1-2):180-6.

80. Roebroeks W, Soressi M. Neandertals revised. Proc Natl Acad Sci U S A. 2016;113(23):6372-9.

81. Jensen RT, Battey JF, Spindel ER, Benya RV. International Union of Pharmacology. LXVIII. Mammalian bombesin receptors: nomenclature, distribution, pharmacology, signaling, and functions in normal and disease states. Pharmacol Rev. 2008;60(1):1-42. 
82. Brothers SP, Wahlestedt C. Therapeutic potential of neuropeptide Y (NPY) receptor ligands. EMBO Mol Med. 2010;2(11):429-39.

83. Berens AJ, Cooper TL, Lachance J. The genomic health of ancient hominins. Hum Biol. 2017;89(1):7-19.

84. Mitselos A, Peeters TL, Depoortere I. Desensitization and internalization of the human motilin receptor is independent of the C-terminal tail. Peptides. 2008;29(7):1167-75.

85. Sanger GJ. Motilin receptor neuropharmacology: revised understanding. Curr Opin Pharmacol. 2012;12(6):641-6.

86. Xiao C, Reitman ML. Bombesin-Like Receptor 3: Physiology of a functional orphan. Trends Endocrinol Metab. 2016;27(9):603-5.

87. Prevete N, Liotti F, Marone G, Melillo RM, de Paulis A. Formyl peptide receptors at the interface of inflammation, angiogenesis and tumor growth. Pharmacol Res. 2015;102:18491.

88. Gunji T, Onouchi Y, Nagasawa T, Katagiri S, Watanabe H, Kobayashi H, et al. Functional polymorphisms of the FPR1 gene and aggressive periodontitis in Japanese. Biochemical and biophysical research communications. 2007;364(1):7-13.

89. Mills JS. Differential activation of polymorphisms of the formyl peptide receptor by formyl peptides. Biochim Biophys Acta. 2007;1772(9):1085-92.

90. Sahagun-Ruiz A, Colla JS, Juhn J, Gao JL, Murphy PM, McDermott DH. Contrasting evolution of the human leukocyte $\mathrm{N}$-formylpeptide receptor subtypes FPR and FPRL1R. Genes Immun. 2001;2(6):335-42.

91. Zhang Y, Syed R, Uygar C, Pallos D, Gorry MC, Firatli E, et al. Evaluation of human leukocyte N-formylpeptide receptor (FPR1) SNPs in aggressive periodontitis patients. Genes Immun. 2003;4(1):22-9.

92. Mills JS. Peptides derived from HIV-1, HIV-2, Ebola virus, SARS coronavirus and coronavirus $229 \mathrm{E}$ exhibit high affinity binding to the formyl peptide receptor. Biochim Biophys Acta. 2006;1762(7):693-703.

93. Mollereau C, Roumy M, Zajac JM. Opioid-modulating peptides: mechanisms of action. Curr Top Med Chem. 2005;5(3):341-55.

94. Quillet R, Ayachi S, Bihel F, Elhabazi K, Ilien B, Simonin F. RF-amide neuropeptides and their receptors in Mammals: Pharmacological properties, drug development and main physiological functions. Pharmacol Ther. 2016.

95. Lima CJ, Cardoso SC, Lemos EF, Zingler E, Capanema C, Menezes LD, et al. Mutational analysis of the genes encoding RFamide-related peptide-3, the human orthologue of gonadotrophin-inhibitory hormone, and its receptor (GPR147) in patients with gonadotrophin-releasing hormone-dependent pubertal disorders. $\mathrm{J}$ Neuroendocrinol. 2014;26(11):817-24.

96. Bray L, Froment C, Pardo P, Candotto C, Burlet-Schiltz O, Zajac JM, et al. Identification and functional characterization of the phosphorylation sites of the neuropeptide FF2 receptor. J Biol Chem. 2014;289(49):33754-66.

97. Steinhoff MS, von Mentzer B, Geppetti P, Pothoulakis C, Bunnett NW. Tachykinins and their receptors: contributions to physiological control and the mechanisms of disease. Physiol Rev. 2014;94(1):265-301.

98. Kim TB, Oh SY, Park HK, Jeon SG, Chang YS, Lee KY, et al. Polymorphisms in the neurokinin-2 receptor gene are associated with angiotensin-converting enzyme inhibitorinduced cough. J Clin Pharm Ther. 2009;34(4):457-64.

99. Park HK, Oh SY, Kim TB, Bahn JW, Shin ES, Lee JE, et al. Association of genetic variations in neurokinin-2 receptor with enhanced cough sensitivity to capsaicin in chronic cough. Thorax. 2006;61(12):1070-5. 
100. Ahlstedt I, Engberg S, Smith J, Perrey C, Moody A, Morten J, et al. Occurrence and pharmacological characterization of four human tachykinin NK2 receptor variants. Biochem Pharmacol. 2008;76(4):476-81.

101. Davenport AP, Hyndman KA, Dhaun N, Southan C, Kohan DE, Pollock JS, et al. Endothelin. Pharmacol Rev. 2016;68(2):357-418.

102. Stobdan T, Zhou D, Ao-Ieong E, Ortiz D, Ronen R, Hartley I, et al. Endothelin receptor $\mathrm{B}$, a candidate gene from human studies at high altitude, improves cardiac tolerance to hypoxia in genetically engineered heterozygote mice. Proc Natl Acad Sci U S A. 2015;112(33):1042530 .

103. Becker A, Haendler B, Hechler U, Schleuning WD. Mutational analysis of human endothelin receptors ETA and ETB identification of regions involved in the selectivity for endothelin 3 or cyclo-(D-Trp-D-Asp-Pro-D-Val-Leu). Eur J Biochem. 1994;221(3):951-8.

104. Slon V, Mafessoni F, Vernot B, de Filippo C, Grote S, Viola B, et al. The genome of the offspring of a Neanderthal mother and a Denisovan father. Nature. 2018.

105. Leeb-Lundberg LM, Marceau F, Muller-Esterl W, Pettibone DJ, Zuraw BL. International union of pharmacology. XLV. Classification of the kinin receptor family: from molecular mechanisms to pathophysiological consequences. Pharmacol Rev. 2005;57(1):2777.

106. Antal-Zimanyi I, Khawaja X. The role of melanin-concentrating hormone in energy homeostasis and mood disorders. J Mol Neurosci. 2009;39(1-2):86-98.

107. Wermter AK, Reichwald K, Buch T, Geller F, Platzer C, Huse K, et al. Mutation analysis of the MCHR1 gene in human obesity. Eur J Endocrinol. 2005;152(6):851-62.

108. Kring SI, Larsen LH, Holst C, Toubro S, Hansen T, Astrup A, et al. Genotypephenotype associations in obesity dependent on definition of the obesity phenotype. Obes Facts. 2008;1(3):138-45.

109. Lutz PE, Kieffer BL. Opioid receptors: distinct roles in mood disorders. Trends Neurosci. 2013;36(3):195-206.

110. Knapman A, Santiago M, Connor M. A6V polymorphism of the human mu-opioid receptor decreases signalling of morphine and endogenous opioids in vitro. Br J Pharmacol. 2015;172(9):2258-72.

111. Levran O, Yuferov V, Kreek MJ. The genetics of the opioid system and specific drug addictions. Hum Genet. 2012;131(6):823-42.

112. Pasternak GW, Pan YX. Mu opioids and their receptors: evolution of a concept. Pharmacol Rev. 2013;65(4):1257-317.

113. Stevens CW. The evolution of vertebrate opioid receptors. Front Biosci (Landmark Ed). 2009;14:1247-69.

114. Song KY, Choi HS, Hwang CK, Kim CS, Law PY, Wei LN, et al. Differential use of an in-frame translation initiation codon regulates human mu opioid receptor (OPRM1). Cellular and molecular life sciences : CMLS. 2009;66(17):2933-42.

115. Meunier JC, Mollereau C, Toll L, Suaudeau C, Moisand C, Alvinerie P, et al. Isolation and structure of the endogenous agonist of opioid receptor-like ORL1 receptor. Nature. 1995;377(6549):532-5.

116. Reinscheid RK, Nothacker HP, Bourson A, Ardati A, Henningsen RA, Bunzow JR, et al. Orphanin FQ: a neuropeptide that activates an opioidlike $\mathrm{G}$ protein-coupled receptor. Science. 1995;270(5237):792-4.

117. Witkin JM, Statnick MA, Rorick-Kehn LM, Pintar JE, Ansonoff M, Chen Y, et al. The biology of Nociceptin/Orphanin FQ (N/OFQ) related to obesity, stress, anxiety, mood, and drug dependence. Pharmacol Ther. 2014;141(3):283-99.

118. Cagliani R, Fumagalli M, Pozzoli U, Riva S, Cereda M, Comi GP, et al. A complex selection signature at the human AVPR1B gene. BMC Evol Biol. 2009;9:123. 
119. Ben-Efraim YJ, Wasserman D, Wasserman J, Sokolowski M. Family-based study of AVPR1B association and interaction with stressful life events on depression and anxiety in suicide attempts. Neuropsychopharmacology. 2013;38(8):1504-11.

120. Abou Jamra R, Schulze TG, Becker T, Brockschmidt FF, Green E, Alblas MA, et al. A systematic association mapping on chromosome $6 \mathrm{q}$ in bipolar affective disorder--evidence for the melanin-concentrating-hormone-receptor-2 gene as a risk factor for bipolar affective disorder. Am J Med Genet B Neuropsychiatr Genet. 2010;153B(4):878-84.

121. Ghoussaini M, Vatin V, Lecoeur C, Abkevich V, Younus A, Samson C, et al. Genetic study of the melanin-concentrating hormone receptor 2 in childhood and adulthood severe obesity. J Clin Endocrinol Metab. 2007;92(11):4403-9.

122. Laitinen T, Polvi A, Rydman P, Vendelin J, Pulkkinen V, Salmikangas P, et al. Characterization of a common susceptibility locus for asthma-related traits. Science. 2004;304(5668):300-4.

123. Pape HC, Jungling K, Seidenbecher T, Lesting J, Reinscheid RK. Neuropeptide S: a transmitter system in the brain regulating fear and anxiety. Neuropharmacology. 2010;58(1):29-34.

124. Anedda F, Zucchelli M, Schepis D, Hellquist A, Corrado L, D'Alfonso S, et al. Multiple polymorphisms affect expression and function of the neuropeptide $S$ receptor (NPSR1). PLoS One. 2011;6(12):e29523.

125. Domschke K, Reif A, Weber H, Richter J, Hohoff C, Ohrmann P, et al. Neuropeptide S receptor gene -- converging evidence for a role in panic disorder. Mol Psychiatry. 2011;16(9):938-48.

126. Donner J, Haapakoski R, Ezer S, Melen E, Pirkola S, Gratacos M, et al. Assessment of the neuropeptide S system in anxiety disorders. Biol Psychiatry. 2010;68(5):474-83.

127. Camilleri M, Carlson P, Zinsmeister AR, McKinzie S, Busciglio I, Burton D, et al. Neuropeptide $S$ receptor induces neuropeptide expression and associates with intermediate phenotypes of functional gastrointestinal disorders. Gastroenterology. 2010;138(1):98-107 e4.

128. Bernier V, Stocco R, Bogusky MJ, Joyce JG, Parachoniak C, Grenier K, et al. Structurefunction relationships in the neuropeptide $\mathrm{S}$ receptor: molecular consequences of the asthmaassociated mutation N107I. J Biol Chem. 2006;281(34):24704-12.

129. Andiappan AK, Nilsson D, Hallden C, Yun WD, Sall T, Cardell LO, et al. Investigating highly replicated asthma genes as candidate genes for allergic rhinitis. BMC Med Genet. 2013;14:51.

130. Okamura N, Hashimoto K, Iyo M, Shimizu E, Dempfle A, Friedel S, et al. Genderspecific association of a functional coding polymorphism in the Neuropeptide $S$ receptor gene with panic disorder but not with schizophrenia or attention-deficit/hyperactivity disorder. Prog Neuropsychopharmacol Biol Psychiatry. 2007;31(7):1444-8.

131. Gottlieb DJ, O'Connor GT, Wilk JB. Genome-wide association of sleep and circadian phenotypes. BMC Med Genet. 2007;8 Suppl 1:S9.

132. Laas K, Eensoo D, Paaver M, Lesch KP, Reif A, Harro J. Further evidence for the association of the NPSR1 gene A/T polymorphism (Asn107Ile) with impulsivity and hyperactivity. J Psychopharmacol. 2015;29(8):878-83.

133. Lennertz L, Quednow BB, Schuhmacher A, Petrovsky N, Frommann I, SchulzeRauschenbach S, et al. The functional coding variant Asn107Ile of the neuropeptide S receptor gene (NPSR1) is associated with schizophrenia and modulates verbal memory and the acoustic startle response. Int J Neuropsychopharmacol. 2012;15(9):1205-15.

134. Novakowski KE, Yap NVL, Yin C, Sakamoto K, Heit B, Golding GB, et al. Humanspecific mutations and positively-selected sites in MARCO confer functional changes. Mol Biol Evol. 2017. 
135. Hubbard TD, Murray IA, Bisson WH, Sullivan AP, Sebastian A, Perry GH, et al. Divergent Ah Receptor Ligand Selectivity during Hominin Evolution. Mol Biol Evol. 2016;33(10):2648-58.

136. Van Laer B, Kapp U, Soler-Lopez M, Moczulska K, Paabo S, Leonard G, et al. Molecular comparison of Neanderthal and Modern Human adenylosuccinate lyase. Scientific reports. 2018;8(1):18008. 
Table 1: Single amino acid variation found in peptide GPCRs from Neanderthal and Denisovan hominins, compared with great apes (Gorilla gorilla and Pan troglodytes) and present-day human frequency.

Blue: ancestral variant shared with apes. Yellow: derived variant (not shared with apes). Green: ancestral and derived variant at around $50 \%$ frequency in present-day population. Orange: derived variant (not shared with apes) different between archaic and present-day humans.

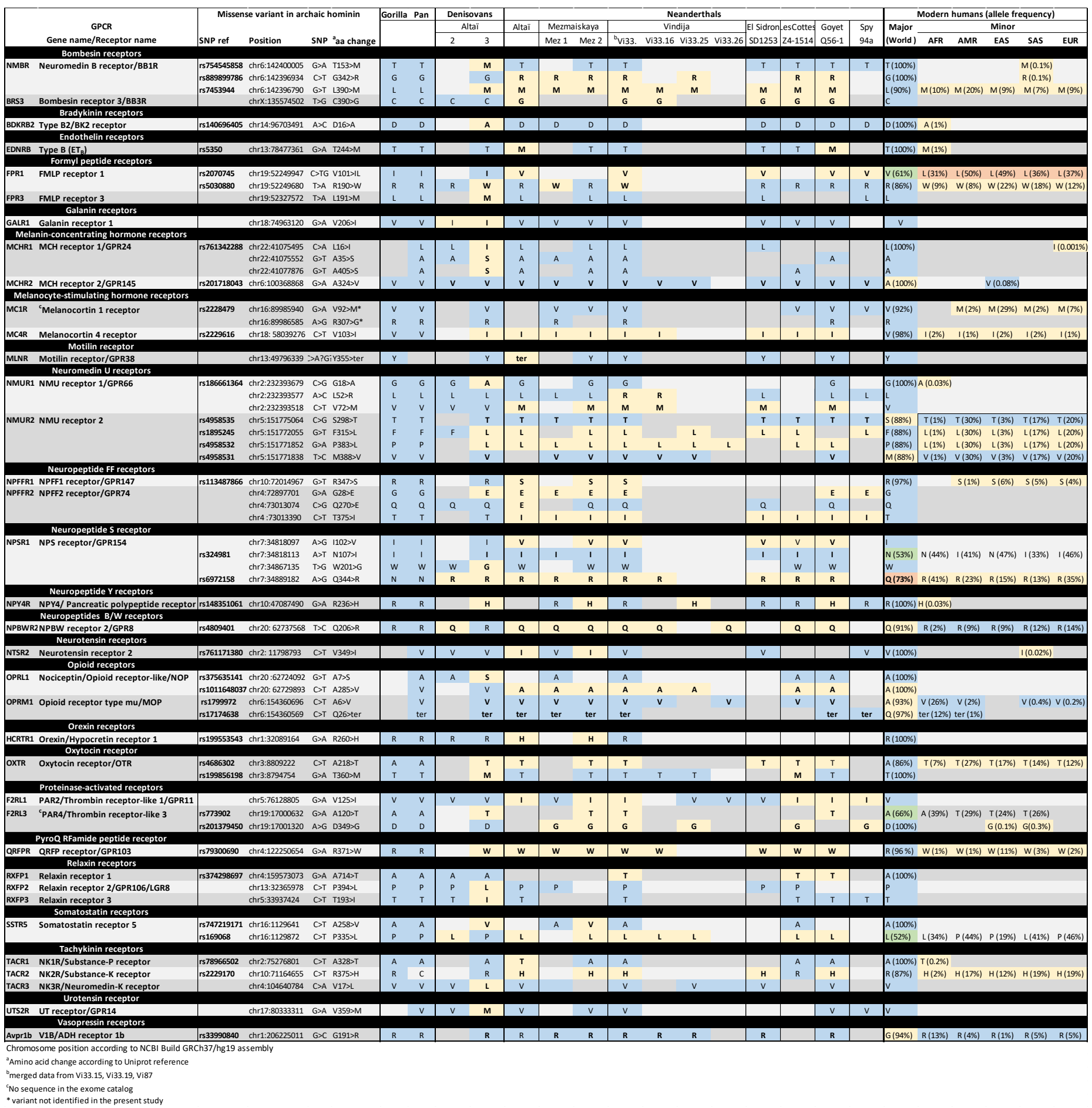


Table 2: Putative functional consequence and phenotype associated with the coding variations in peptide GPCRs from Neanderthal and Denisovan hominins.

${ }^{a}$ Amino acid change according to Uniprot reference.

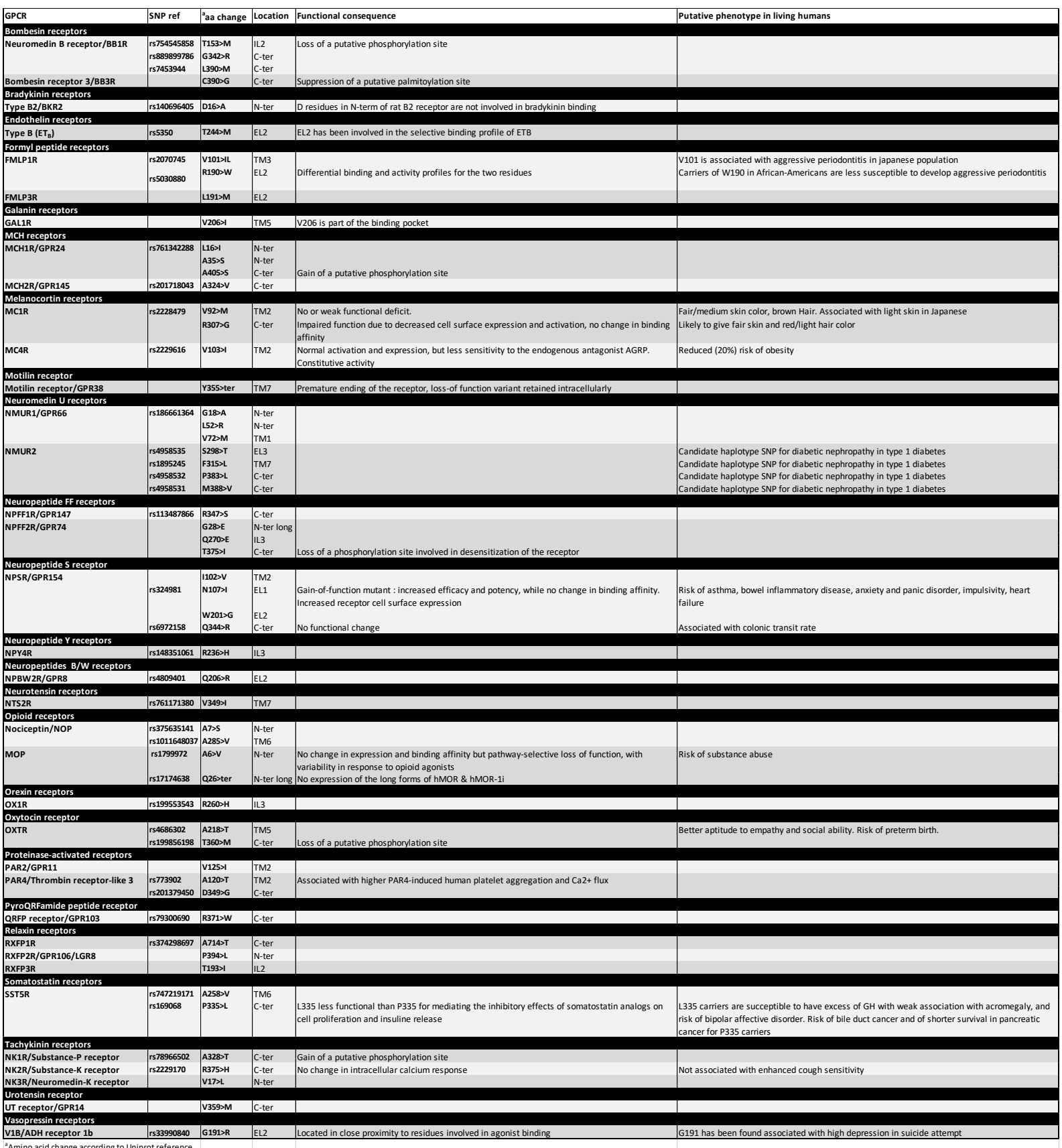




\section{Legend to figures}

Figure 1: Simplified representation of GPCR-mediated signal transduction $(31,35)$.

The binding of endogenous or exogenous agonist ligand on a specific receptor induces conformational changes that propagate through the receptor towards the closely associated heterotrimeric G-proteins, catalyzing GDP/GTP exchange on their $\alpha$ subunit. Depending on the subtype ( $\alpha$ s, $\alpha \mathrm{i}, \alpha \mathrm{q}, \alpha \mathrm{o}$ ), the activated $\alpha$ subunit stimulates (or inhibits) downstream enzymes such as adenylyl cyclases or phospholipases, while the $\beta \gamma$ subunits interact with effectors such as ion channels $\left(\mathrm{Ca}^{++}, \mathrm{K}^{+}\right)$, promoting thus the production of signaling molecules activating cell-specific pathways. GTP hydrolysis allows the cycle to restart. Phosphorylation of the receptor on specific intracellular residues by G-protein receptor kinases (GRK) or Protein Kinases $\mathrm{A}$ and $\mathrm{C}$, contributes to feedback regulation and arrest by mechanisms involving interaction with arrestins, and/or receptor desensitization or internalization. The insert represents a GPCR with the amino acid motifs characteristic of the Family A. The ellipse shows the binding pocket in the particular case of peptide receptors, that involves extracellular loops, including the $\mathrm{N}$-terminus, and the upper part of the transmembrane domain.

Figure 2: Distribution of receptors and associated physiological roles according to the dendrograms of the relationships between the main archaic variants and the corresponding variants in primates and present-day humans. 
Figure 1:

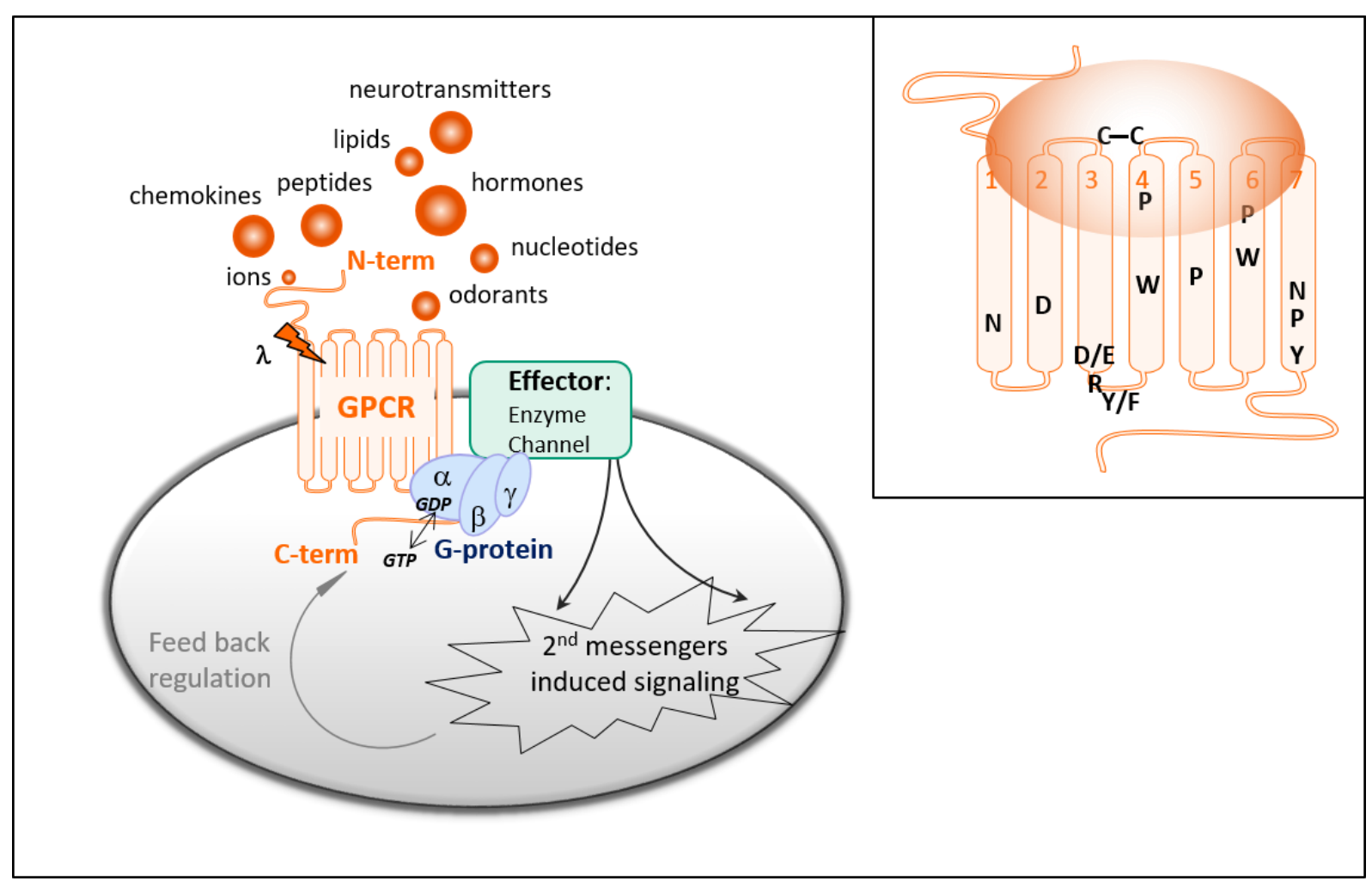




\section{Figure 2:}
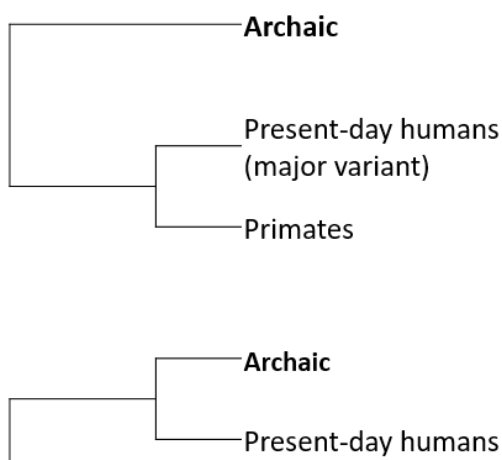

Present-day humans

-Primates

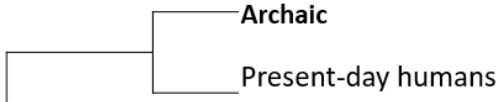

(minor variant)

Primates

Present-day humans

(major variant)

\section{Archaic}

Primates
BB1R, BB3R, FMLP1R, MC4R, NPFFR, QRFP, NK2R, OTR, PAR2, PAR4

Food intake, Energy homeostasis

Pain regulation, Visceral pain, Inflammation, Immune response Uterine/gastrointestinal/pulmonary/urinary tract contractions Vasculature relaxation, Hemostasis, Angiogenesis

Bone formation, Reproductive axis

Social interaction, Stress, Reward

\section{FMPLP1R, NPSR}

Inflammation, Immune response

Angiogenesis

Food intake

Anxiety, Arousal

NMUR2

Food intake

Bone formation

\section{MOP, MCHR2, NPSR, V1B}

Pain regulation, Inflammation

Mood, Anxiety, Arousal

Food intake,

Social interaction, Reward

Energy homeostasis 


\section{Supplementary Information}

Table S1: List of the peptide GPCRs analyzed in the present study

\begin{tabular}{|c|c|c|}
\hline Gene ID & $\begin{array}{l}\text { Gene } \\
\text { name }\end{array}$ & Receptor name \\
\hline ENSG00000144891 & AGTR1 & Angiotensin II receptor, type 1/AT1 \\
\hline ENSG00000180772 & AGTR2 & Angiotensin II receptor, type 2/AT2 \\
\hline ENSG00000134817 & APLNR & Apelin receptor/APJ/HG11 \\
\hline ENSG00000135577 & NMBR & Bombesin receptor 1/Neuromedin B receptor/BB1R \\
\hline ENSG00000126010 & GRPR & Bombesin receptor $2 /$ Gastrin-releasing peptide receptor/BB2R \\
\hline ENSG00000102239 & BRS3 & Bombesin receptor $3 / \mathrm{BB} 3 \mathrm{R}$ \\
\hline ENSG00000100739 & BDKRB1 & bradykinin receptor $\mathrm{B} 1 / \mathrm{BK} 1$ receptor \\
\hline ENSG00000168398 & BDKRB2 & bradykinin receptor $\mathrm{B} 2 / \mathrm{BK} 2$ receptor \\
\hline ENSG00000163394 & CCKAR & Cholecystokinin A receptor/CCKIR \\
\hline ENSG00000110148 & CCKBR & Gastrin/Cholecystokinin B receptor/CCK2R \\
\hline ENSG00000171860 & C3AR1 & C3a anaphylatoxin chemotactic receptor \\
\hline ENSG00000197405 & C5AR1 & C5a anaphylatoxin chemotactic receptor 1 \\
\hline ENSG00000134830 & C5AR2 & C5a anaphylatoxin chemotactic receptor 2/GPR77 \\
\hline ENSG00000151617 & EDNRA & Endothelin receptor type A/ETA receptor/Endothelin-1 receptor \\
\hline ENSG00000136160 & EDNRB & Endothelin receptor type B/ETB receptor \\
\hline ENSG00000170775 & GPR37 & Endothelin receptor type B-like/GPR37 \\
\hline ENSG00000171051 & FPR1 & Formyl peptide receptor 1 \\
\hline ENSG00000171049 & FPR2 & Formyl peptide receptor 2 \\
\hline ENSG00000187474 & FPR3 & Formyl peptide receptor 3 \\
\hline ENSG00000166573 & GALR1 & Galanin receptor 1 \\
\hline ENSG00000182687 & GALR2 & Galanin receptor 2 \\
\hline ENSG00000128310 & GALR3 & Galanin receptor 3 \\
\hline ENSG00000109163 & GNRHR & Gonadotropin-releasing hormone receptor \\
\hline ENSG00000184194 & GPR173 & Putative Gonadotropin-releasing hormone receptor/GPR173 \\
\hline ENSG00000211451 & GNRHR2 & Putative Gonadotropin-releasing hormone receptor 2 \\
\hline ENSG00000121853 & GHSR & Growth hormone secretagogue receptor/Ghrelin receptor \\
\hline ENSG00000116014 & KISS1R & Kisspeptin receptor $1 /$ GPR54 \\
\hline ENSG00000128285 & MCHR1 & Melanin-concentrating hormone receptor 1/GPR24 \\
\hline ENSG00000152034 & MCHR2 & Melanin-concentrating hormone receptor 2/GPR145 \\
\hline ENSG00000258839 & MC1R & $\begin{array}{l}\text { *Melanocortin } 1 \text { receptor/Melanocyte-stimulating hormone } \\
\text { receptor }\end{array}$ \\
\hline ENSG00000185231 & $\mathrm{MC} 2 \mathrm{R}$ & Melanocortin 2 receptor/Adrenocorticotropic hormone receptor \\
\hline ENSG00000124089 & MC3R & Melanocortin 3 receptor \\
\hline ENSG00000166603 & MC4R & Melanocortin 4 receptor \\
\hline ENSG00000176136 & MC5R & Melanocortin 5 receptor \\
\hline ENSG00000102539 & MLNR & Motilin receptor/GPR38 \\
\hline ENSG00000171596 & NMUR1 & Neuromedin U receptor 1/GPR66 \\
\hline
\end{tabular}




\begin{tabular}{|ll} 
ENSG00000132911 & NMUR2 \\
ENSG00000148734 & NPFFR1 \\
ENSG00000056291 & NPFFR2 \\
ENSG00000187258 & NPSR1 \\
ENSG00000164128 & NPY1R \\
ENSG00000185149 & NPY2R \\
ENSG00000204174 & NPY4R \\
ENSG00000226306 & NPY6R \\
ENSG00000183729 & NPBWR1 \\
ENSG00000125522 & NPBWR2 \\
ENSG00000101188 & NTSR1 \\
ENSG00000169006 & NTSR2 \\
ENSG00000125510 & OPRL1 \\
ENSG00000116329 & OPRD1 \\
ENSG00000082556 & OPRK1 \\
ENSG00000112038 & OPRM1 \\
ENSG00000121764 & HCRTR1 \\
ENSG00000137252 & HCRTR2 \\
ENSG00000180914 & OXTR \\
ENSG00000119973 & PRLHR \\
ENSG00000181104 & F2R \\
ENSG00000164251 & F2RL1
\end{tabular}

ENSG00000164220 F2RL2

ENSG00000127533 F2RL3

ENSG00000186867 QRFPR

ENSG00000171509 RXFP1

ENSG00000133105 RXFP2

ENSG00000182631 RXFP3

ENSG00000173080 RXFP4

ENSG00000139874 SSTR1

ENSG00000180616 SSTR2

ENSG00000183473 SSTR3

ENSG00000132671 SSTR4

ENSG00000162009 SSTR5

ENSG00000115353 TACR1

ENSG00000075073 TACR2

ENSG00000169836 TACR3

ENSG00000174417 TRHR

ENSG00000181408 UTS2R

ENSG00000166148 Avpr1a

ENSG00000198049 Avpr1b
Neuromedin U receptor 2

Neuropeptide FF receptor 1/NPFF1/GPR147

Neuropeptide FF receptor 2/NPFF2/GPR74

Neuropeptide S receptor GPR154

Neuropeptide Y receptor Y1

Neuropeptide Y receptor Y2

Neuropeptide Y receptor Y4/ Pancreatic polypeptide receptor 1

Neuropeptide Y receptor Y5

*Putative Neuropeptide Y receptor Y6

Neuropeptides B/W receptor 1/GPR7

Neuropeptides B/W receptor 2/GPR8

Neurotensin receptor 1

Neurotensin receptor 2

Opioid receptor-like 1/Nociceptin receptor/NOP

Opioid receptor delta/DOP

Opioid receptor kappa $1 / \mathrm{KOP}$

Opioid receptor, $\mathrm{mu} / \mathrm{MOP}$

Orexin receptor 1/ Hypocretin receptor 1

Orexin receptor 2/ Hypocretin receptor 2

Oxytocin receptor

Prolactin releasing hormone receptor/PrRP receptor/GPR10

Proteinase-activated receptor $1 /$ Thrombin receptor/PAR1

Proteinase-activated receptor $2 /$ Thrombin receptor-like

1/PAR2/GPR11

Proteinase-activated receptor 3/Thrombin receptor-like 2/PAR3

*Proteinase-activated receptor 4/Thrombin receptor-like 3/PAR4

Pyroglutamylated RFamide peptide receptor/QRFP

receptor/GPR103

Relaxin receptor 1

Relaxin receptor 2/GPR106

Relaxin receptor 3

Relaxin receptor 4/GPR100

Somatostatin receptor 1

Somatostatin receptor 2

Somatostatin receptor 3

Somatostatin receptor 4

Somatostatin receptor 5

Tachykinin receptor $1 /$ Substance-P receptor/NK1R

Tachykinin receptor 2/Substance-K receptor/NK2R

Tachykinin receptor 3/Neuromedin-K receptor/NK3R

Thyrotropin-releasing hormone receptor

Urotensin 2 receptor/GPR 14

Vasopressin receptor 1A/V1A/Antidiuretic hormone receptor 1a

Vasopressin receptor $1 \mathrm{~B} / \mathrm{V} 1 \mathrm{~B} /$ Antidiuretic hormone receptor $1 \mathrm{~b}$ 
* No sequence read for these receptors in the Neanderthal exome catalog from (23)

Table S2 (Excel file): Coverage of the nsSNP in the less intensively sequenced archaic hominins

The first sheet recapitulates the following sheets of individual analyses and includes the high coverage and USER treated samples (shaded columns). C>T and G>A changes are indicated in bold to point out a possible damage-induced modification. 
Table S3: Physiological role of the peptide GPCRs analyzed in the present study.

\begin{tabular}{|c|c|}
\hline $\begin{array}{c}\text { GPCR } \\
\text { Gene ID/Gene name/Uniprot accession/Receptor name }\end{array}$ & Physiological role \\
\hline Bombesin receptors & \\
\hline P28336 Neuromedin B receptor/BB1R & Gastrointestinal and urogenital contractions, satiety, stress, inhibition of TSH release \\
\hline P32247 Bombesin receptor 3/BB3R & Regulation of energy balance and body weight \\
\hline Bradykinin receptors & \\
\hline ENSG00000168398 BDKRB2 P30411 Type B2/BK2 receptor & Inflammatory response and pain \\
\hline Endothelin receptors & \\
\hline P24530 Type B (ET $\left.T_{B}\right)$ & Regulation of the cardiovascular system \\
\hline Formyl peptide receptors & \\
\hline ENSG00000171051 FPR1 P21462 FMLP receptor 1 & Regulation of inflammation and immune response, angiogenesis \\
\hline ENSG00000187474 FPR3 $\quad$ P25089 FMLP receptor 3 & Immune system \\
\hline Galanin receptors & \\
\hline ENSG00000166573 GALR1 P47211 Galanin receptor 1 & Regulation of stress, reward, neuroendocrine secretion \\
\hline Melanin-concentrating hormone receptors & \\
\hline ENSG00000128285 MCHR1 Q99705 MCH receptor 1/GPR24 & Stimulation of food intake and decrease in energy expenditure \\
\hline ENSG00000152034 MCHR2 Q969V1 MCH receptor 2/GPR145 & Mood and energy homeostasis \\
\hline Melanocortin/Melanocyte-stimulating hormone receptors & \\
\hline ENSG00000258839 MC1R Q01726 Melanocortin 1 receptor & Melanogenesis \\
\hline P32245 Melanocortin 4 receptor & Energy homeostasis and food intake \\
\hline Motilin receptor & \\
\hline ENSG00000102539 MLNR 043193 Motilin receptor/GPR38 & Gastroin \\
\hline Neuromedin U receptors & \\
\hline ENSG00000171596 NMUR1 Q9HB89 NMU receptor 1/GPR66 & Stress, reduction of food intake and body weight \\
\hline ENSG00000132911 NMUR2 Q9GZQ4 NMU receptor 2 & Inhibition of food intake and bone formation \\
\hline Neuropeptide FF receptors & \\
\hline ENSG00000148734 NPFFR1 Q9GZQ6 NPFF1 receptor/GPR147 & Regulation of the reproductive axis \\
\hline ENSG00000056291 NPFFR2 Q9Y5X5 NPFF2 receptor/GPR74 & Regulation of nociception, reward, food intake \\
\hline Neuropeptide S receptor & \\
\hline ENSG00000187258 NPSR1 Q6W5P4 NPS receptor/GPR154 & Arousal, decreased anxiety and food intake, inflammation \\
\hline Neuropeptide $Y$ receptors & \\
\hline ENSG00000204174 NPY4R P50391 NPY4/ Pancreatic polypeptide receptor & Reduction of food intake \\
\hline Neuropeptides B/W receptors & \\
\hline ENSG00000125522 NPBWR2 P48146 NPBW receptor 2/GPR8 & Food \\
\hline Neurotensin receptors & \\
\hline ENSG00000169006 NTSR2 095665 Neurotensin receptor 2 & Pain inhibition \\
\hline $\begin{array}{l}\text { Opioid receptors } \\
\end{array}$ & \\
\hline ENSG00000125510 OPRL1 P41146 Nociceptin/Opioid receptor-like/OFO/NOP & Nociception, stress, memory \\
\hline ENSG00000112038 OPRM1 P35372 Opioid receptor type mu/MOP & Pain inhibition, reward \\
\hline Orexin receptors & \\
\hline $\begin{array}{c}\text { ENSG00000121764 HCRTR1 } 043613 \text { Orexin/Hypocretin receptor } 1 \\
\text { Oxytocin receptor }\end{array}$ & Stimulation of food intake, sleep-wake cycle, stress \\
\hline ENSG00000180914 OXTR $\quad$ P30559 Oxytocin receptor/OTR & Uterine contractions at birth, social interaction \\
\hline Proteinase-activated receptors & \\
\hline ENSG00000164251 F2RL1 $\quad$ P55085 $\quad$ PAR2/Thrombin receptor-like 1/GPR11 & Vasculature relaxation, inflammation, nociception \\
\hline ENSG00000127533 F2RL3 Q96RIO PAR4/Thrombin receptor-like 3 & Hemostasis and thrombosis, visceral pain \\
\hline $\begin{array}{l}\text { PyroQ RFamide peptide receptor } \\
\end{array}$ & \\
\hline Q96P65 QRFP receptor/G & \\
\hline Relaxin receptors & \\
\hline ENSG00000171509 RXFP1 Q9HBX9 Relaxin receptor 1 & Reproduction, metabolism, cardiovascular regulation \\
\hline ENSG00000133105 RXFP2 Q8WXD0 Relaxin receptor 2/GPR106/LGR8 & Reproduction, metabolism, cardiovascular regulation \\
\hline ENSG00000182631 RXFP3 Q9NSD7 Relaxin receptor 3 & Reproduction, metabolism, cardiovascular regulation \\
\hline Somatostatin receptors & \\
\hline ENSG00000162009 SSTR5 P35346 Somatostatin receptor 5 & Inhibition of the release of pituitary (GH, TSH, Prolactine), gastrointestinal and pancre \\
\hline \begin{tabular}{llll} 
& \multicolumn{2}{c}{ Tachykinin receptors } \\
ENSG00000115353 TACR1 & P25103 & NK1R/Substance-P receptor
\end{tabular} & Inflammatory response and pain \\
\hline ENSG00000075073 TACR2 P21452 NK2R/Substance-K receptor & Gastrointestinal, pulmonary, urinary tract contractions \\
\hline ENSG00000169836 TACR3 P29371 NK3R/Neuromedin-K receptor & Regulation of the reproductive axis \\
\hline Urotensin receptor & \\
\hline Q9UKP6 UT receptor/GPR14 & Vasoconstriction \\
\hline Vasopressin receptors & \\
\hline ENSG00000198049 Avpr1b P47901 V1B/ADH receptor 1b & Mood, anxiety, social interaction, energy storage \\
\hline
\end{tabular}

